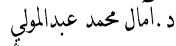

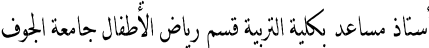

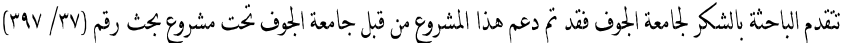

هدفت الدر اسة الحالبة إلي دعرفة مدى فاعلية برنامج تدريبى فى تحسين بعض المهارات التكريسية لدى الطالبات/ المعلمات فى كلبة الثزبية قسم رياض الأطفال بجامعة الجوف وتأثير ذللك على التفكير الإباعى لطفل الروضة، وطبق البرنامج على الطالبات (عبنة الدر اسة) المتربات فى الروضات الحكومية الرابعة والسابعة فى مدينة

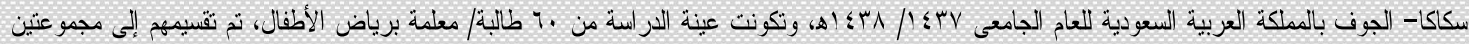

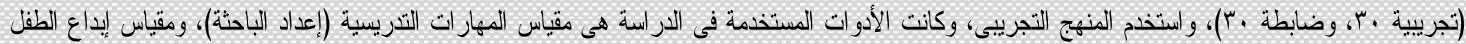

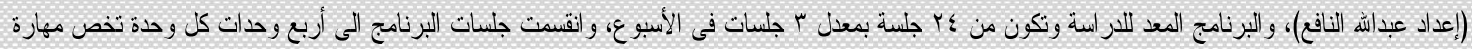

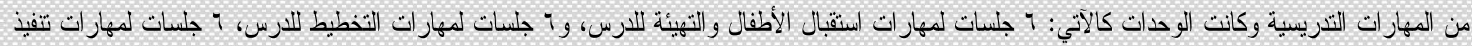

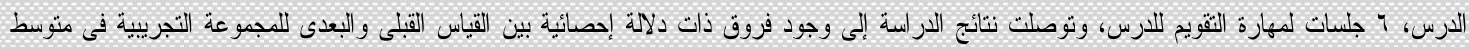

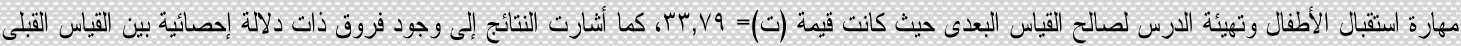

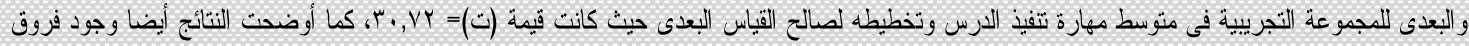

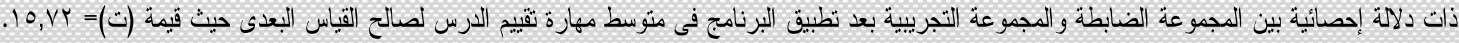

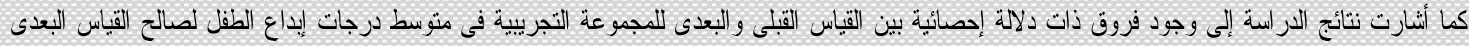

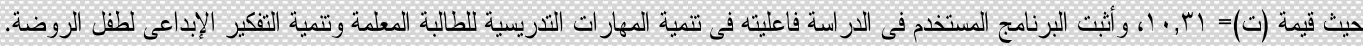

Effectiveness of a Training Program to Improve Some Teaching Skills of the Student/ Teacher at Al- Jouf University and Its Impact on Creative Thinking for Kindergarten children

The current study aimed at finding out the effectiveness of a training program in improving some of the teaching skills of female students at the Faculty of Education, Department of Kindergartens at Al-Jouf University, and the impact on the creative thinking of the Kindergarten child. The program was applied to the female students (sample of the study) trainees in the fourth and seventh government kindergartens in the city of SkakaAljouf in Saudi Arabia for the academic year 1437/1438AH. The sample of the study consisted of 60 female kindergarten teachers who were divided into two groups: experimental 30 and female 30 . The experimental method was used, and the tools used were In the study, (prepared by the author), and the measure of creativity of the child (prepared by Abdullah Nafi), and the program prepared for the study consists of (24) sessions, with a rate of 3 sessions per week. The program is divided into four units, each unit represents a teaching skill. 6 sessions for the skills of receiving children and preparing for the lesson, 6 sessions of the planning skills of the lesson, 6 sessions of the skills of the implementation of the lesson, and 6 sessions of the skill of the evaluation lesson. The results of the study concluded to the existence of differences of statistical significance between the tribal and remote measurement of the experimental group in the average skill of receiving the children and preparing the lesson for the benefit. The results of the study revealed that there were statistically significant differences between the tribal and post-experimental measurement of the experimental group in the average skill of receiving the children and the preparation of the lesson for the benefit of the telemetry where the value of $T=33.79$. The results also indicated that there were statistically significant differences between the tribal and postexperimental measurements of the experimental group in the average skill of implementation of the lesson and its planning for the benefit of the telemetry. The value of $\mathrm{T}=30.72$. The results also showed that there were significant differences between the control group and the experimental group After the application of the program in the average skill of assessment of the lesson in favor of distance measurement where the value of $\mathrm{T}=$ 15.72. The results of the study showed that there are statistically significant differences between the pre-test and the experimental group in the average grade of the child's creativity in favor of the dimension measurement, where the value of $T=10.31$. The program used in the study proved its effectiveness in developing the teacher's teaching skills and developing the creative thinking of the kindergarten child. 
وفى ضوء هذه المرحلة. لذلك تم توجيه المزيد من الاهتمام لتطوير بر امج إعداد الماد

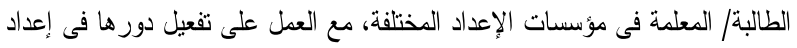

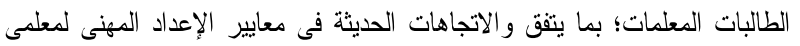

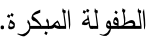

كما تؤكد الاتجاهات العالمية الحديثة فى بر امج إعداد معلمة رياض الأطفال على

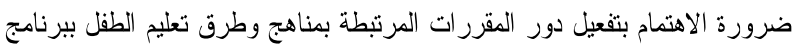

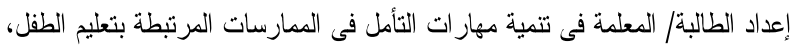

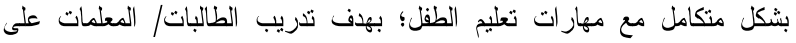
التشريس المنظم ذاتيا، بما بسهم فى تطويرهن الذاتى لممارساتهن التعليمية بشكل

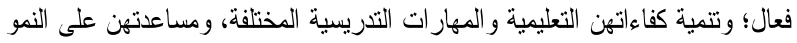

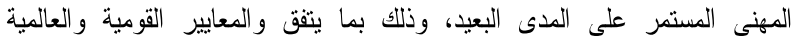

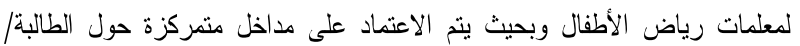

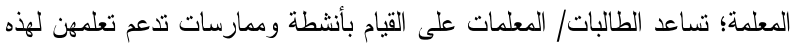

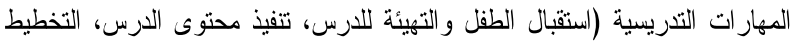

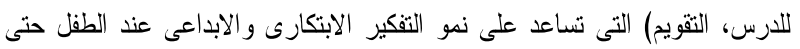

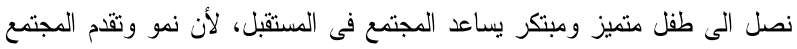
ينتج من نطور عقول وفكر أبنائه. ويمكنا القول أن الصراع بين الدول المتقدمة هو صانه صراع بين عقول أبنائها من

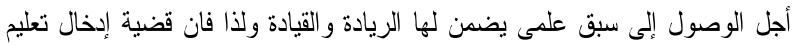

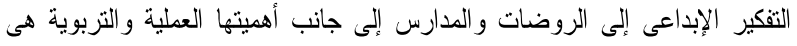
قضية تتعلق بمسألة النمو والتقدم ومواجهة تحديات المستقبل فى عالم أصبح قائده

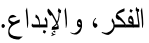

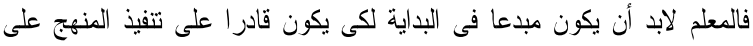

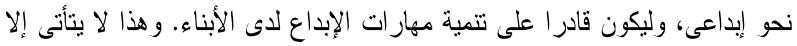

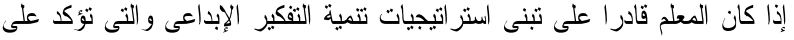

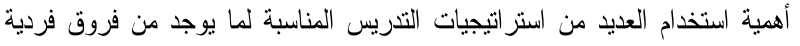

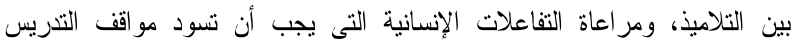

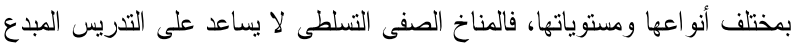

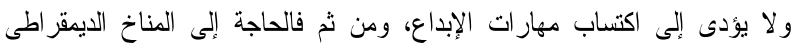

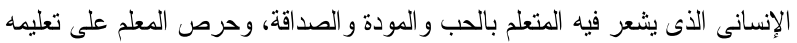

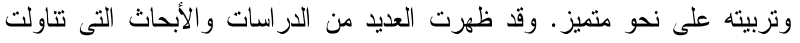

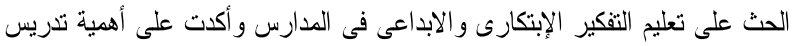

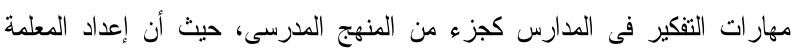
لتستخدم طريقة فى التدريس تشجع التفكير الإبداعي لدى الأطفال قد يكون له له الفعالية

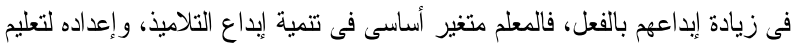

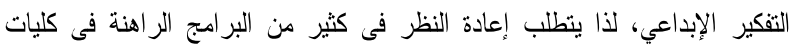

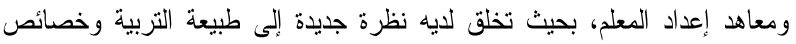

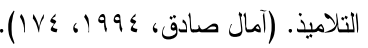

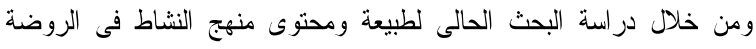
وسمات وخصائص مرحلة رياض الأطفال، وتحليل الأدوار المتعددة المنوطة لمعلمة

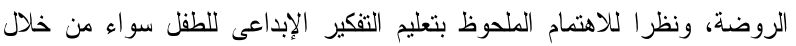

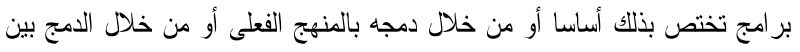

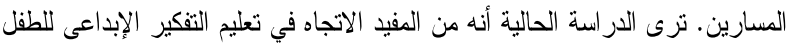

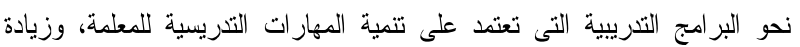

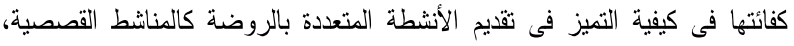

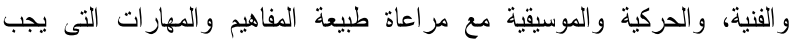

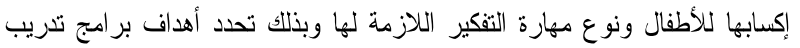
المعلمة فى إطار الإبتكار و الأبداع فى هدفين أساسيين متكاملين أقرب إلى ألى أن يكونا
يتوقف نجاح أى مجتمع فى تحقيق أهدافه ومتابعة نموه وتطوره على الكفاية

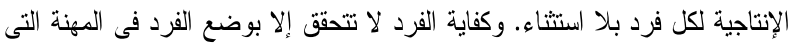

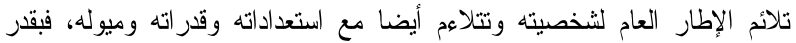
كفايته فى عمله وتكيفه فيه، ينجح فى أداء رسالته لذا كان اختيار الأفراد لكهنة

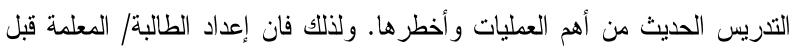

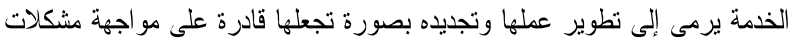

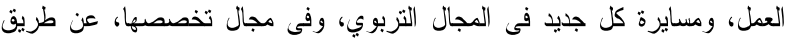
التوجيه و الإرشاد و إكسابها خبرات ومهار ات جديدة بما تحتويه من ميول و واتجاهات ومفاهيم وأساليب تفكير ابتكارية تؤدى إلى رفع مستوى أدائها المهني.

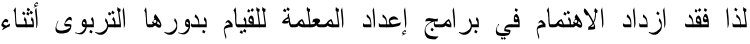

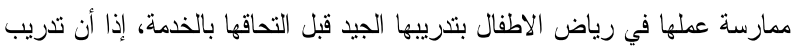

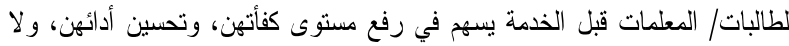

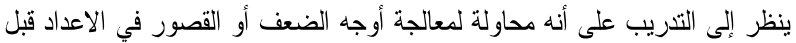
الخدمة فحسب بل ينظر إليه على أنه جزء من التربية المستمرة للمعلمة طيلة

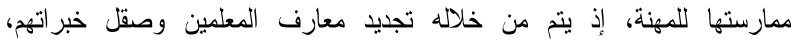

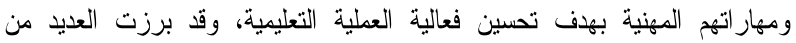

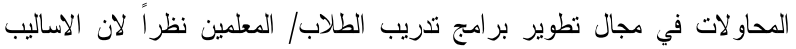
التقليدية لم تعد قادرة على مو اكبة التغيرات التي طر أت في في العملية التعليمية، وكان

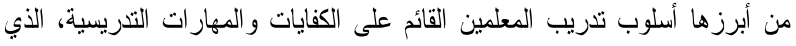

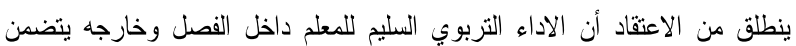

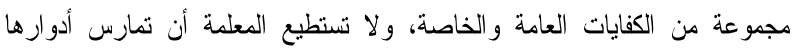

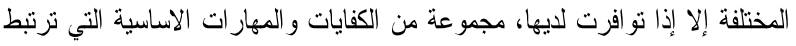

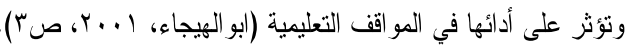

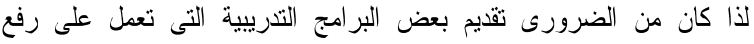

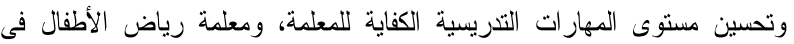

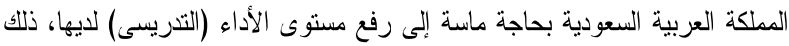
لأن تحقيق الأهداف المرغوبة فيها فى نلك المرحلة مرهون بدرجة كبيرة بنوعية

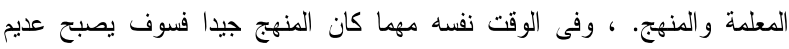
الجدوى دون تو افر المعلمة القادرة على تتفيذه بشكل جيد. إضافة إلى تعدد مستويات المعلمات من حيث المؤهلات و الخبر ات و المهار ات التدريسية وعدد الدورات التدريبية كل ذلك يفرض تدرييا مستمر أثناء الخدمة، ويستوجب ثقويما مستمر الإدخال التحسينات على الو اقع التعليمى للطفل، حيث تتسابق المجتمعات فى جميع الميادين، ووسيلتها فى ذلك استثمار كل طاقاتها و إمكاناتها وثرواتها، وعلى رأسها الثروة

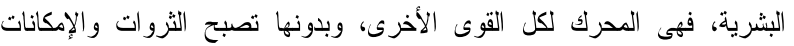

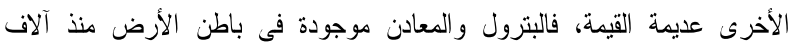
السنين، و الشمس موجودة منذ بدء الخليقة. ولم تتحول هذه المصادر إلى تلك الطاقة

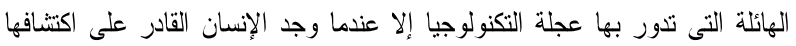
و استغلالها، ولم يكن ذللك وليد الصدفة، ولكن نتيجة لإعمال الفكر، و الجهد الذي بذله الذهانه

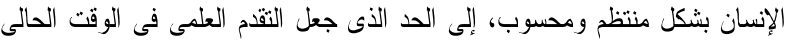

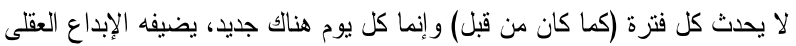
للإنسان، من أجل نطوير الحياة الإنسانية، وتحقيق التقدم و الرخاء.

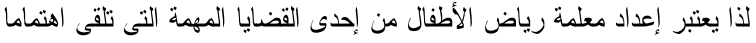

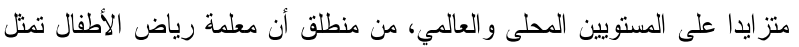

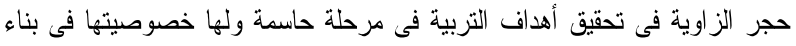

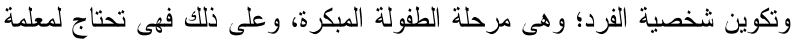
تمتلك من المهار ات ما بساعدها على تحقيق أهداف تربية الطفل، بما يتفق ومعايير

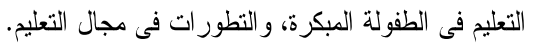


للمعلم فى اكتساب المهارات المعرفية، و إعداده بقدرات متتوعة من أجل تلبية احتياجاته ومتطلباته حتى يساير عصر العولمة بكل مستحدثاته ومستجداته، وبحيث ونيث يمتلك قدرات التعامل مع هذه المتغير ات بعد إعدادا مهنيا جيدا لكى يكون لايه القدرة

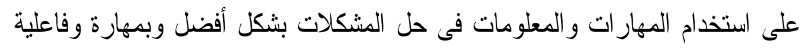

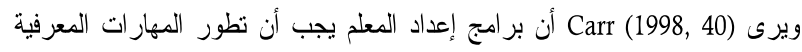
للطلاب المعلمين لتكون أكثر فاعلية وفائدة لتلاميذهم الذين سيتعلمون منهم كما يجب إنب

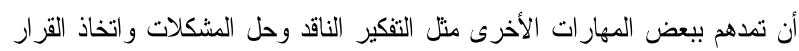

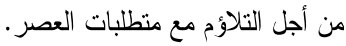

وتزى الباحثة أن الطالبة المعلمة تحتاج إلى برامج تدريبية أثثاء عملها فى مجال

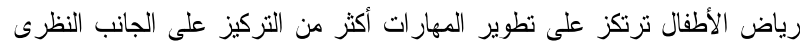

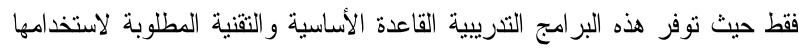

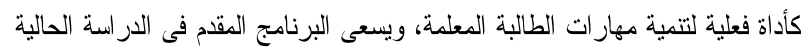

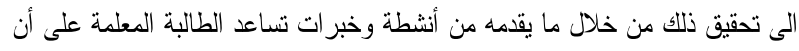
تؤدى دورها في الروضة بإتقان وتميز .

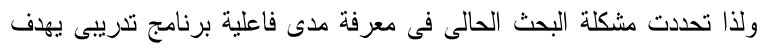

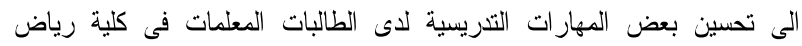

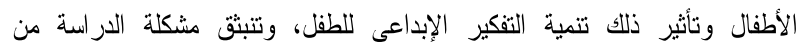

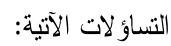
1. ما فاعلية البرنامج المعد فى الدراسة الحالية فى تحسين بعض المهار ات التدريسية

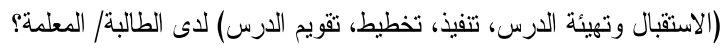

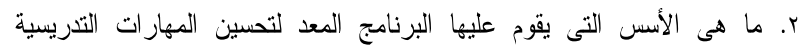

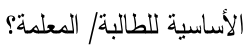

ז. هل هناك فروق دالة احصائيا بين درجات المجموعة التجريبية قبل وبعد تطبيق

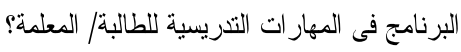

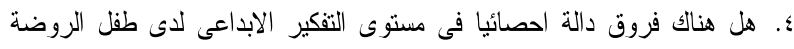

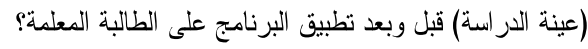

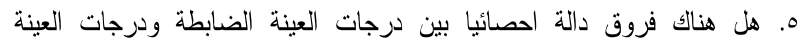
التجريبية قبل وبعد تطبيق البرنامج?

أهدان الدراسة:

1. تهدف الدراسة الحالية إلى تصميم برنامج لتدريب الطالبات المعلمات على تحسين بعض المهار ات التدريسية الأساسية.

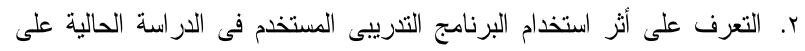

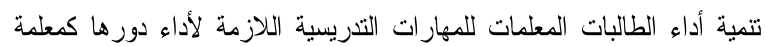
رياض الأطفال بكفائة وجودة. r. كما تهاف الدراسة الى معرفة أثر تحسين المهارات التدريسية لاى الطالبة المعلمة على تتمية التفكير الإبداعى لدى طفل الروضة. لقدئ.

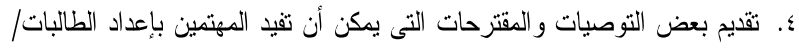

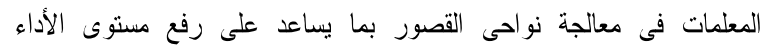
التدريسى فى تلك المهار ات التذريسية.

أهمية الدراسة:

1. تستمد الدراسة الحالية أهميتها من أهمية الموضوع الذى تسعى لدراسته إذ تعتبر

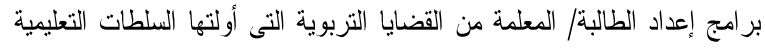

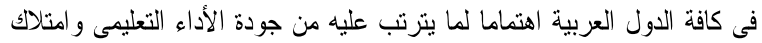
المعلمين للمهار ات و القدر ات التربوية. r. توفير برنامج تدريبى يمكن الاسترشاد به فى إعداد وتدريب الطالبات/ المعلمات

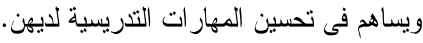

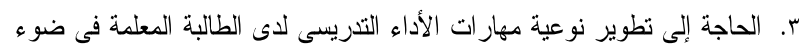
استر اتيجية إعداد المعلمين.
وجهين لعملة واحدة، يتعلق إحداهما تغيير اتجاهات المعلمين نحو أهداف التعليم

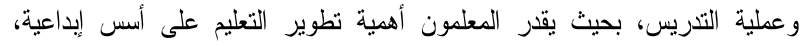

و الثانى يتعلق بتمكين المعلمين من التدريس من أجل الإبداع (فايز مينا، ... ب. ب).

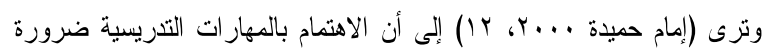

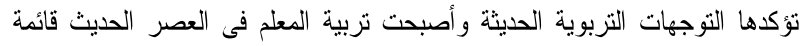

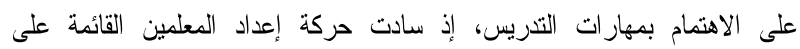

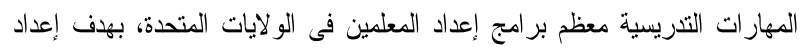
معلمين ماهرين قادرين على أداء عملهم التدريسى على نحو سليم. وترى (نادية

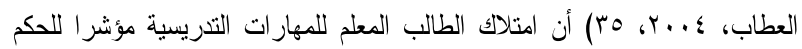
على مدى نجاحه فى عمله وقدرته على أداء مهماته بكفاءة وفاعلية.

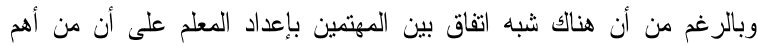

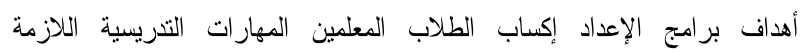

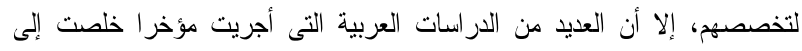

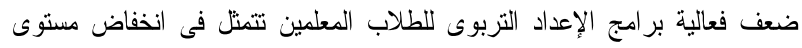

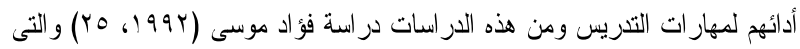
هدفت إلى معرفة فاعلية برنامج لتدريب الطلاب المعلمين شعبة الرياضيات بكلية

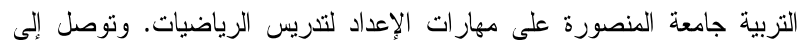
فاعلية البرنامج التدريبى فى اكتساب الطلاب المعلمين تلك المهارة، ودر اسة إسماعيل

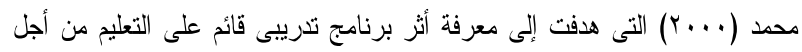

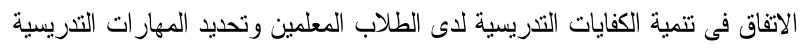
الأساسية اللازمة للطلاب المعلمين بكليات التربية، وتثويم أداء الطلاب المعلمين

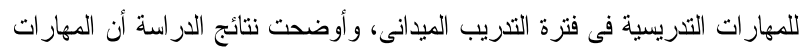

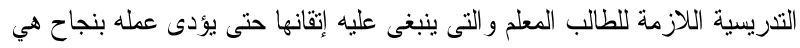

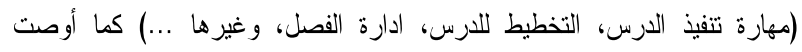

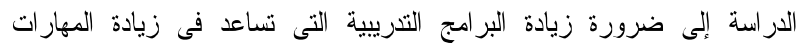
التدريسية للطلاب/ المعلمين وترفع من كفاءتهر.

مثعة البحث:

مسايرة هذا العصر يتطلب إعداد أجيال قادرة على التعامل مع المتغيرات الحديثة

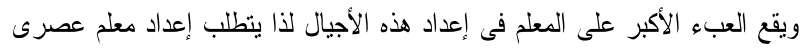

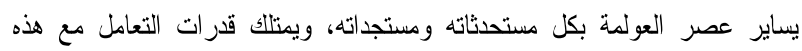
المتغير ات ويعد إعداد مهنيا جيدا، ويكون متفهما لدوره ومكانته.

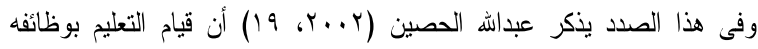

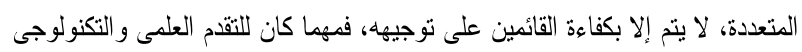

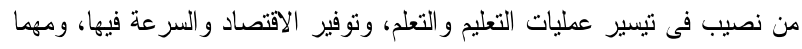

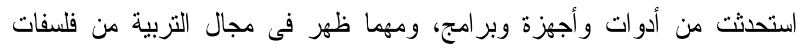
ونظريات و اتجاهات، فإن جودة التعليم وكفاءته لا يمكن أن تتحقق إلا بالمعلم المؤهل القادر على أداء دوره بنجاح وفاعلية.

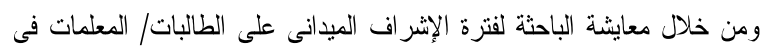

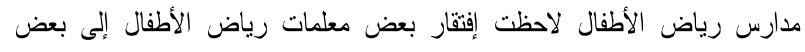

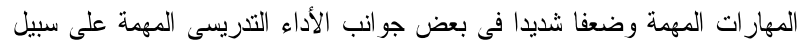

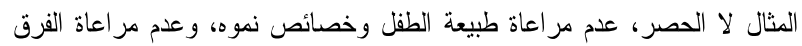

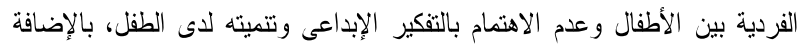

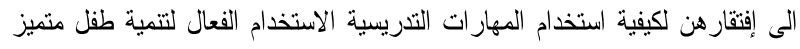

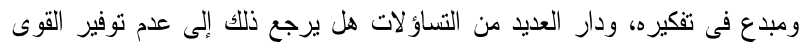

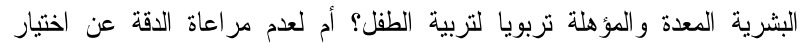

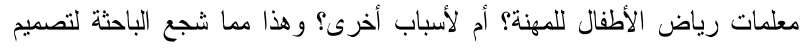

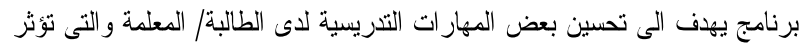

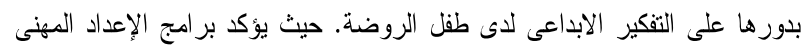


تحليه ببعض السمات الشخصية كالإتزان الإنفعالى وقوة الشخصية والصبر ، كما

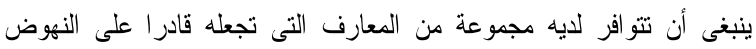
بأعباؤه المهنية، لذا لابد من اكتسابه مجموعة من المهارات التدريسية اللازمة

اللنجاح فى العطلية التعليمية

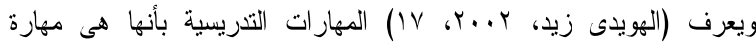
التخطيط التى يجب أن يتسم بها أداء المعلم عند قيامه بتخطيط و إعداد دروسه

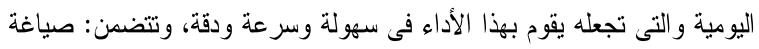
الأهداف بعبار ات محددة قابلة للقياس- تحديد استر اتيجيات التنريس و الأنشطة

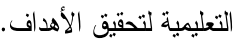

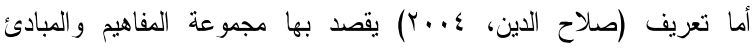

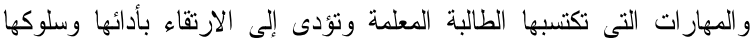
التشريسى وتتكون المهارة التشريسية من مكونات ثلاثة:

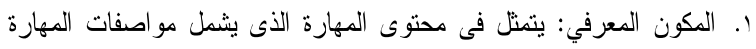

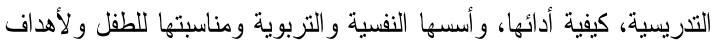

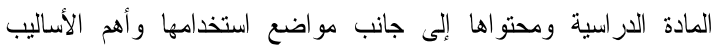

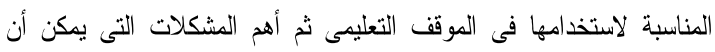

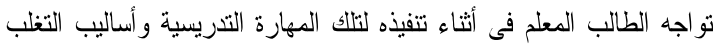
r. المكون المهاري: يتمثل فى أسلوب الطالبة/ المعلمة فى أداء مهارة التدريس،

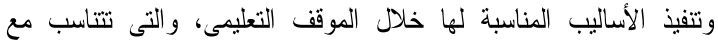

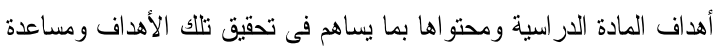

$$
\text { التلاميذ على التعلم. }
$$

r. المكون النفسي: يتمثل فى رغبة الطالبة المعلمة فى تعلم المهارة التدريسية

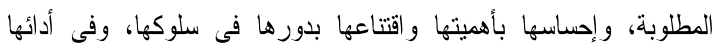

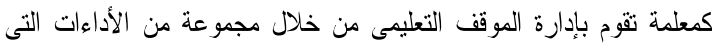
تشكل فى مجملها المهارة التدريسية.

و هذه المكونات الثثلاث تأتى متداخلة بصورة شاملة فى أداء مهارة التشريس أثناء الموقف التعليمى بحيث تبدو المهارة فى صورة مجملة ولكن من خلال أداء مجموعة من الإجراءات والتكنيكات التى تتناسب مع المهارة التدريسية (صلاح

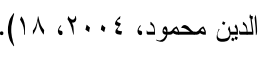

口 التفكير الإبداعي Creative Thinking: يعريفه محمود منسى (1991: على أنه قدرة الفرد على التفكير الحر الذى يككنه من اكتشات المشكلات

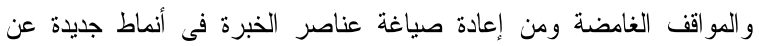
طريق تقديم أكبر عدد ممكن من البدائل لإعادة صياغة هذه الخبه الخبرة بأساليب

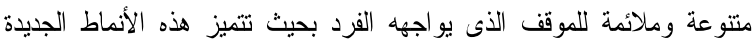

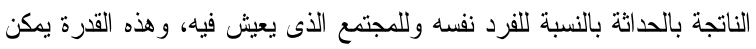

التتريب عليها وتنميتها.

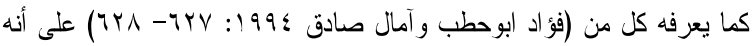

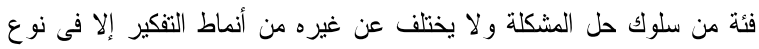

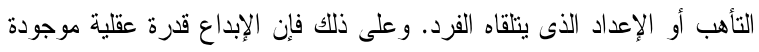

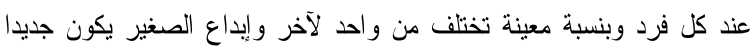
بالنسبة إليه حتى ولو كان معروفا للكبار .

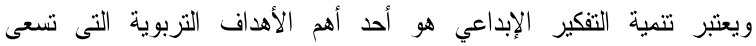

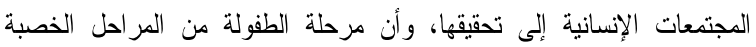

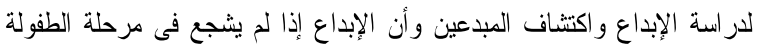

فإن نشجيعه بعد ذلك يكون ضعيف الجدوى. لإبوان.

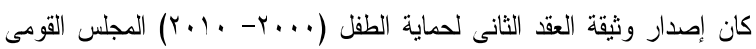
للطفولة والأمومة كإثشارة البدء لأن تحتل قضايا الطفولة مكانها اللائق من لطن
؛. إمكانية الوصول لبرنامج إثرائى فاعل لتطوير مهارات الأداء التنريسى المهنية للطالبة المعلمة للحصول على مخرجات تعليمية عالية.

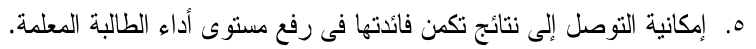

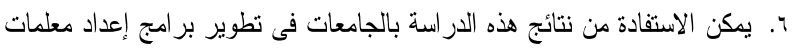

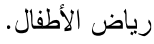

V. إفادة صانعى القرارات بالتعليم العام وخاصة في تدريب الطالبة المعلمة على الاطى

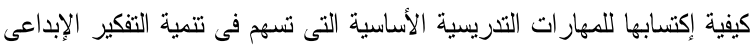
و الإبتكارى لطفل الروضة.

^. إثراء الدراسة بالأدبيات السابقة والحديثة التى تتاولت متغيرات الدراسة بكافة

جو انبها.

9. قد تقتح هذه الدراسة مجالا أمام باحثين آخرين لدراسات تربوية أخرى ومحاولة تتاول كفايات لم تتناولها هذه الدر اسة.

جدوه الدر اسة:

تقتصر الدر اسة الحالية فى إجر اءاتها ونتائجها على الحدود الموضوعية و الزمانية

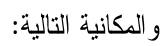
ه الحد الموضوعي: تحسين بعض مهارات الأداء التدريسية الأساسية للطالبة المعلمة لرياض الأطفال.

I 1 الحد المكاني: طالبات الفرقة الر ابعة فى قسم رياض الأطفال كلية التربية جامعة

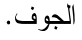

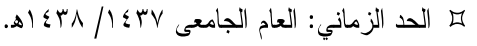

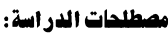

口 المهار ات التدريسية: تعرفها الباحثة على انها مجموعة الخبرات و المهارات التى التى

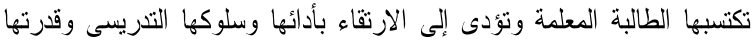
على التعامل مع طفل الروضة بمهارة ومراعاة للفروق الفردية بين الأطفال

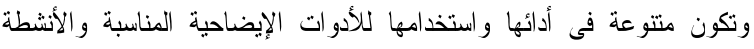
و الألعاب التى تساعد على تتمية التفكير الإبداعى لدى الطفل.

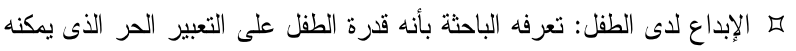

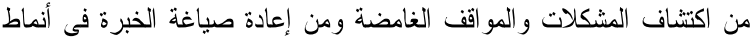
جديدة عن طريق تقديم أكبر عدد مكن من الاستجابات والأنشطة غير المألوفة،

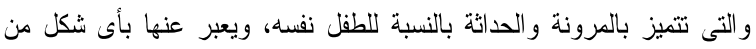

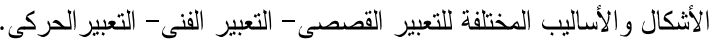

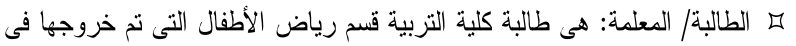
التربية الميدانية. 口 البرنامج: تعرفه سعدية بهادر للبرنامج بأنه مجموعة الأنشطة والألعاب

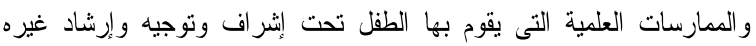

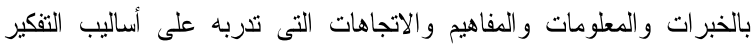

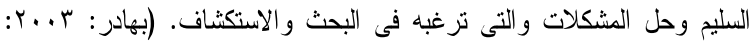
التعريف الإجر ائي: تعرفه الباحثة بأنه مجموعة المعلومات و الأنشطة والخبرات

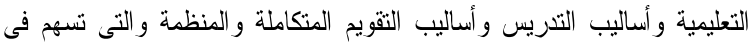
تتمية المهار ات التدريسية لدى الطالبات المعلمات.

الإطار النظرى للبحث:

I المهارات التدريسية: إن لكل مهنة مهارتها الفنية التى تمكن صاحبها من ممارستها بنجاح وفاعلية، ومهنة التنريس لها العديد من المهارات التى يتعين

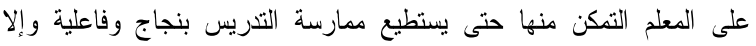

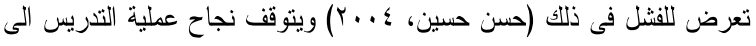
حد كبير على الدور الذى يقوم به المعلم فى العطلية التعليمية، ولكى يقوم المعلم

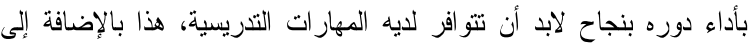




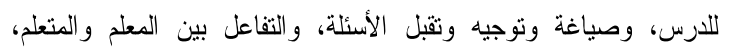

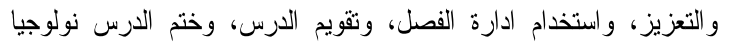

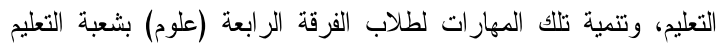

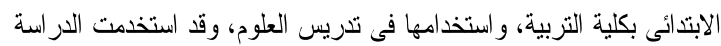

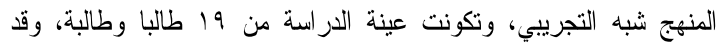

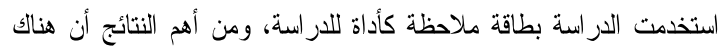

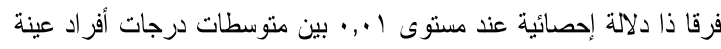

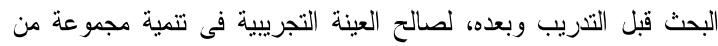

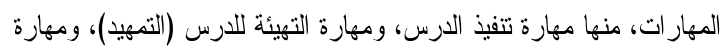
عرض الحقائق و المفاهيم العلمية (المحتوى العلمى للارس)، ومهارة صياغة

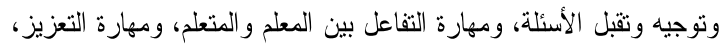

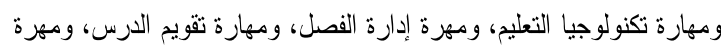
ختم (غلق) الدرس، وهذا الفرق لصالح أفراد العينة بعد تطبيق التجربة وهنة عليهم.

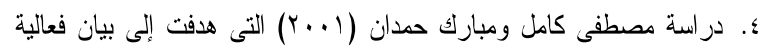

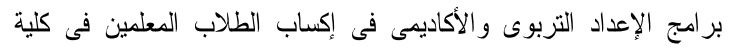

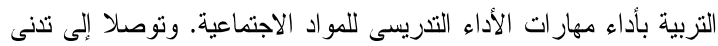

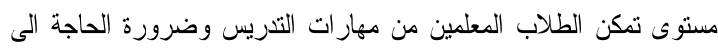
برامج تدريبية لتتمية المهارات التدريسية للطلاب المعلمين لأن الإعداد الأكاديمى وحده لا يكفى، لذا لابد من التدريب على كيفية استخدام المهارة وتطوير ها لدى الطلاب المعلمين من خلال بر امج معدة لذلك. لآلك.

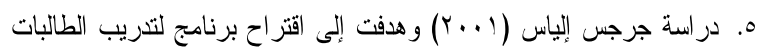

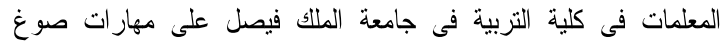

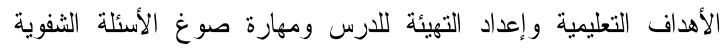

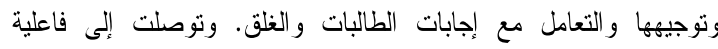

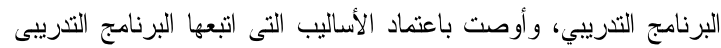
فى تدريب الطلاب المعلمين فى شتى مهار ات التشريس.

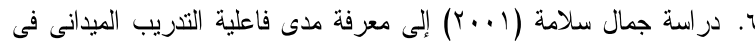

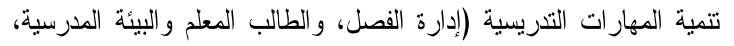

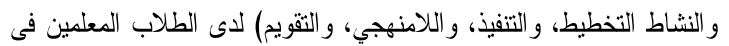

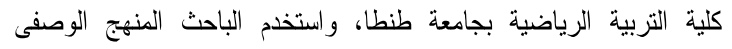

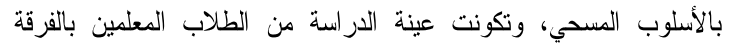

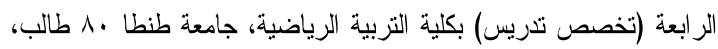

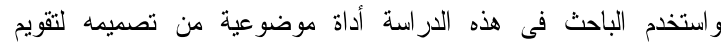

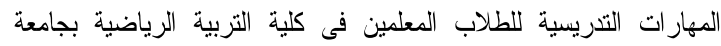

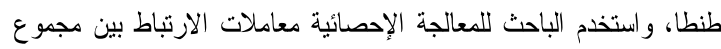
درجات كل بعد من أبعاد البطاقة والدرجة الكلية لكل بعد من أبعاد البطاقة،

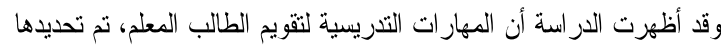

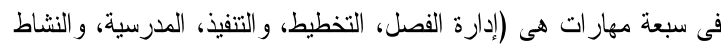

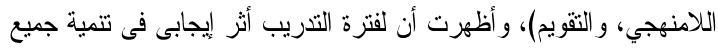
المهار ات التدريسية قيد البحث، بالإضافة إلى الدرجة الكلية للبطاقة.

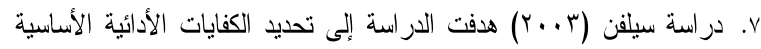

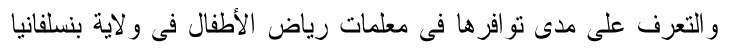

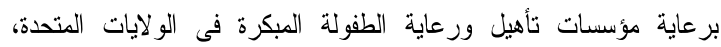
وتوصلت الباحثة إلى ال1 الى سبعة كفايات منها كفايات التخطيط و التقويم

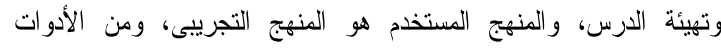

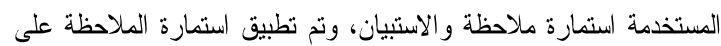

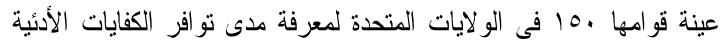

الاهنمام باعتبارها المركز والجوهر لكل خطط المستقبل ولكل آفاق الثقدم ولابد من إعداد الأطفال الذين هم رجال الغذ وأمل المستقبل من خلال تنشئتهم على وهلى تقافة قو امها الإبداع وجعل التفكير الإبداعي هو منهج التعامل مع الحياة.

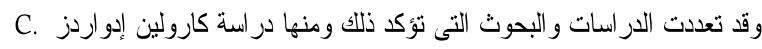

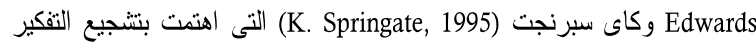
الإبداعى فى فصول الروضة وأهية التفكير الإبداعي للطفل.

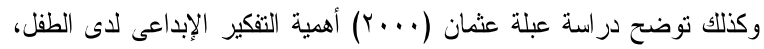

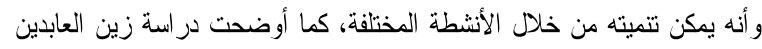

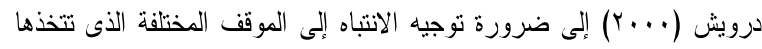

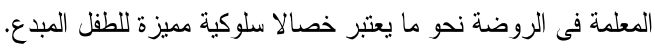

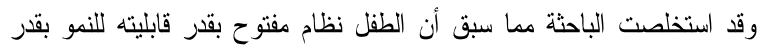

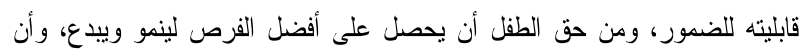

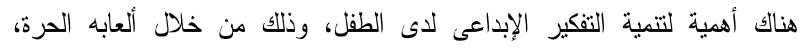
والإيهامية، ومن خلال الأنشطة الفنية المختلفة التى تساعد على تأصيل مجموعة الأدية

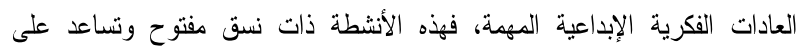

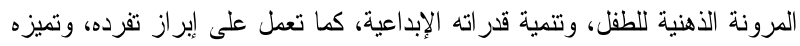

عن الآخرين.

الدر اسات السابقة:

ه أو لا در اسات تتاولت المهار ات التنريسية و علاقتها بالمتغيرات الآخرى: 1. دراسة الكرش (•199) و هدفت إلى معرفة بعض الكفايات المتطلبة لمعلمات

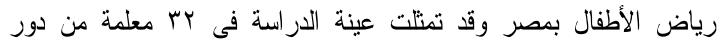

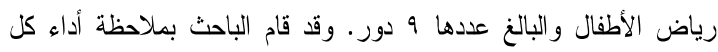

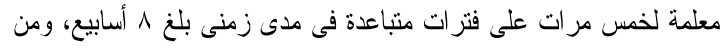

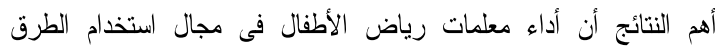

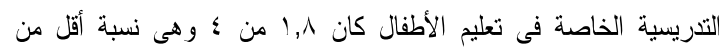

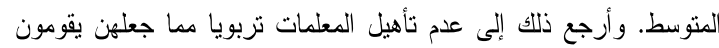
بتعليم الأطفال القراهة و الكتابة واعطاء و اجبات منزلية فى هذه المرحلة من

التعليم. بان.

r. دراسة لاندرز، ويفر (Landers\& Weaver, 1991) هدفت إلى حصر مجموعة الكفايات التدريسية من وجهة نظر مجموعة كبيرة من المعلمين،

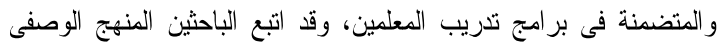

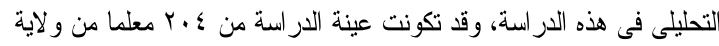
أو هايو بالو لايات المتحدة الأمريكية، وقد قام الباحثين بتصميم استبانة للتحقق لهان

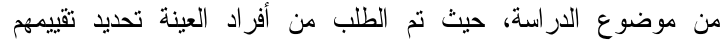

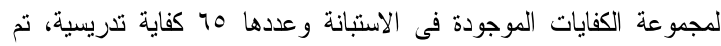
اعتبار ها كفايات تدريسية هامة لمعلى الطلبة المعاقين، وقد تم اعتبارها

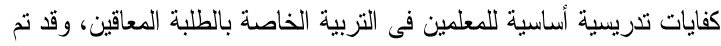

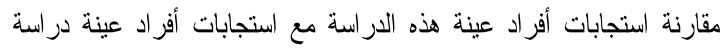

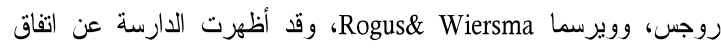

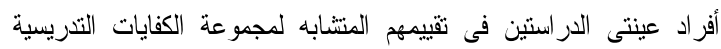

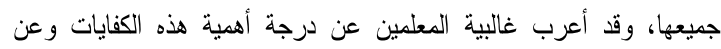

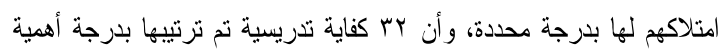

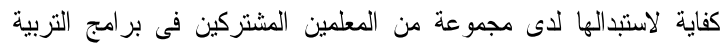

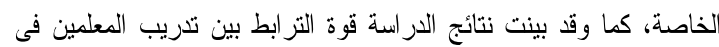

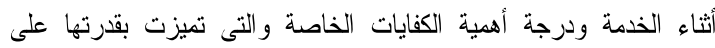
مشاركة غالبية معلمى التربية الخاصة فى التعاون. r. دراسة كوثر الشريف (1997) و هدفت إلى معرفة أثر الترريب على مهار ات

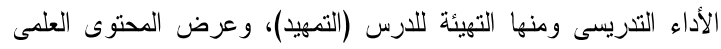




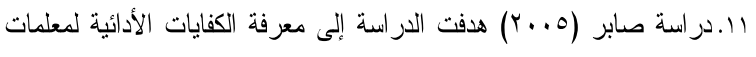

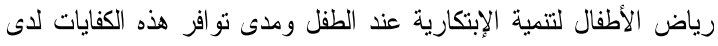

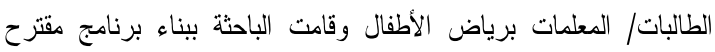

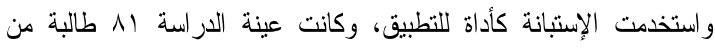
طالبات رياض الأطفال تغطى منطقة جدة بالمملكة العربية السعودية،

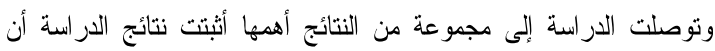

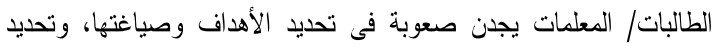
المفاهيم الإجر ائية، ولديهن صعوبة أيضا فى فهم الوسيلة التعليمية و أهميتها

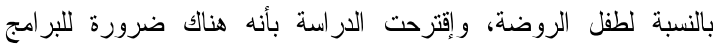
التدريبية لتطوير أداء الطالبة/ المعلمة.

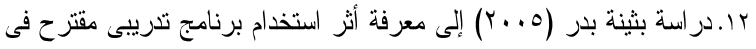

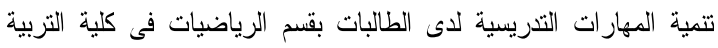

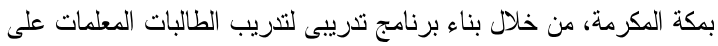

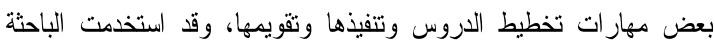

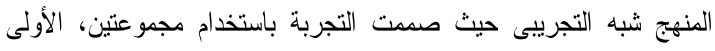
تجريبية تم تدرييها على البرنامج المقترح، و الثانية ضابطة لم يتئ تدريبها

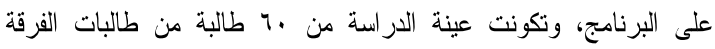

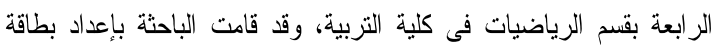
ملاحظة والبرنامج التدريبى ومن ثم تطبيقهما على عينة الدراسة التجريبية،

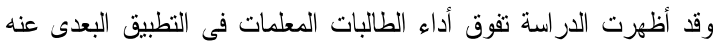

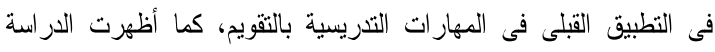

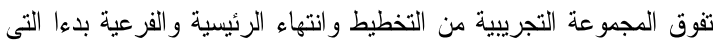

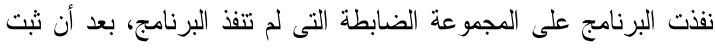

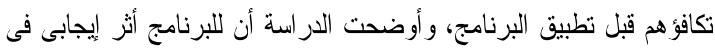

تتمية المهار ات النتريسية الرئيسية و المهار ات الفرعية المندرجة تحتها.

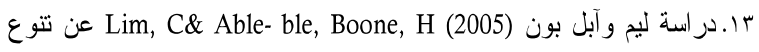
الكفايات لإعداد معلم مرحلة الطفولة المبكرة ممار اسات إيداعية و إتجاهات مستقبلية وهدفت الدراسة الى تحديد مجموعة من الكفايات اللازمة لمعلم

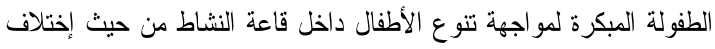
تثافتهم وقدر اتهم، وقد تم تحديد كفايات المساوة فى التعامل مع كل الأطفال

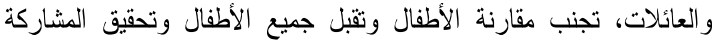
المجتمعية للتعامل مع سلوكيات الأطفال.

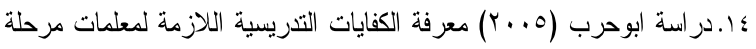
رياض الاطفال وهدفت دراسة أبوحرب ضوء تطوير نماذج المنهج للقرن الحادي والعشرين وهي "المنهج المطور لرياض الاطفال في دول الخليج

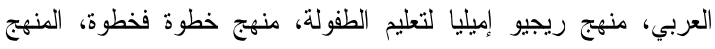

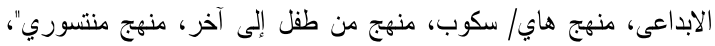

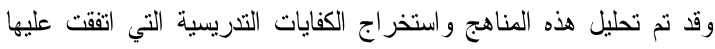

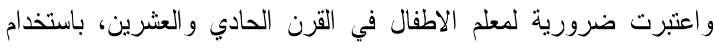

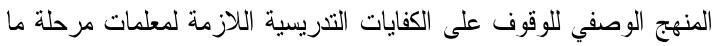

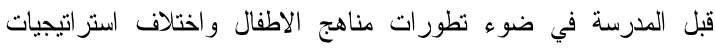

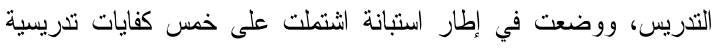
رئيسة وتحت كل كفاية رئيسة ما يندرج تحتها من كفايات فرعية، تكونت عينة الدراسة نظرياً من مشاريع المناهج التي طرحت رئه رؤيا جديدة للكفايات

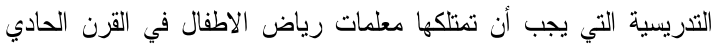

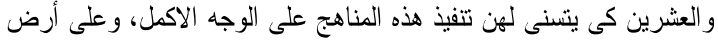

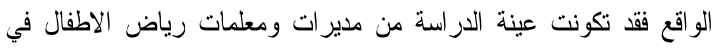

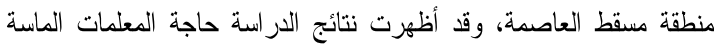

التعليمية لديها، ومن أهم النتائج التى توصلت إليها الدراسة تحديد قائمة

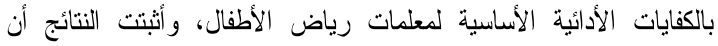

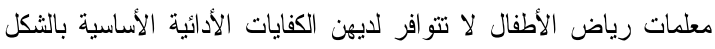

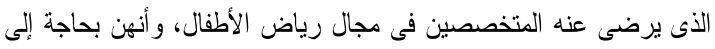
المزيد من بر امج التتريبية التى تساعد فى رفع الكفائة لايهن.

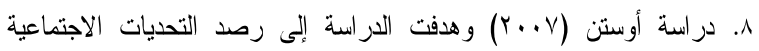
و التقافية المعاصرة التي تو اجه المعلم في مؤسسات ومعاهد إعداد المعلمين

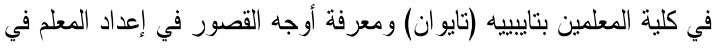

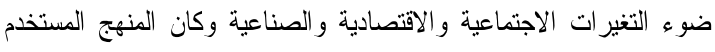

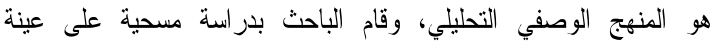

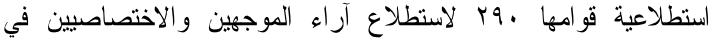

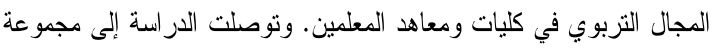

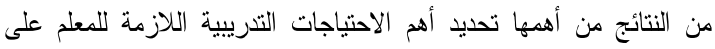

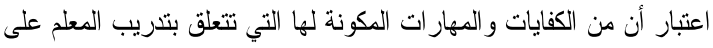

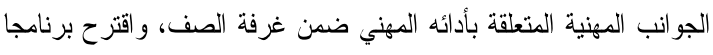
ناتجا عن دراسته لاحتياجاته في ضوء الواتو اقع والتحديات، وقسم الباحث

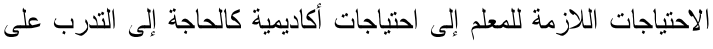

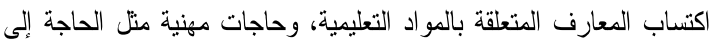

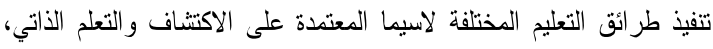
وحاجات ثقافية كالحاجة إلى الاطلاع على المعارن الثقافية العامة.

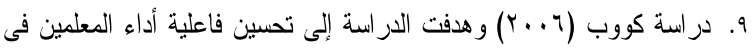

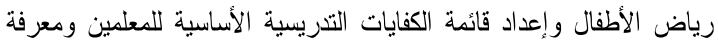
أهميتها بالنسبة لهم من وجهة نظر المختصين التزبويين في الو لايات المتحدة

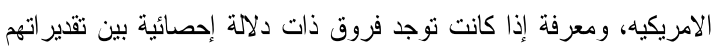

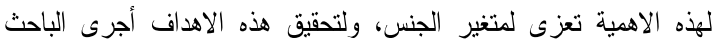

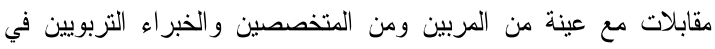
مدارس الصين المتوسطة بلغ عددها بN9 وطبقت استبانة تضمنت أسئلة مفتوحة وجهت إليهم بهدف تحديد الكفايات المهمة وتضمن هذا الاستبيان

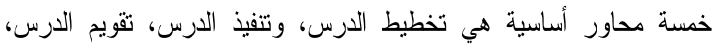

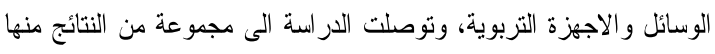
كفاية ضرورية وجاءت تقدير ات المعلمين وحصل الباحث من خلال إجابات

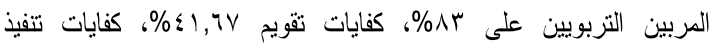
التدريس 11,74\% على النحو الاتى كفايات تخطيط التنريس، الكفايات

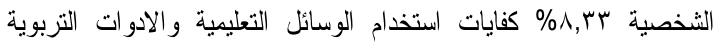

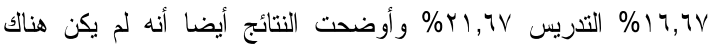

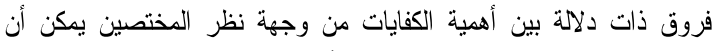

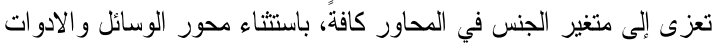

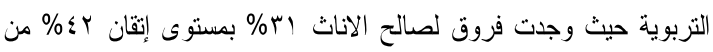

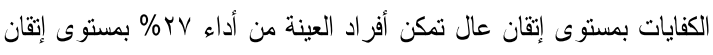
منخفض.

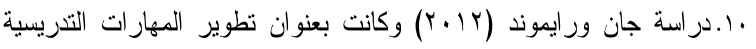

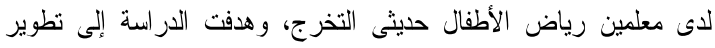

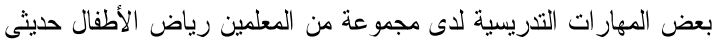

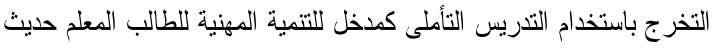
التخرج، وكانت عينة الدراسة .؛؛ معلم ومعلمة رياض أطفال حديثى

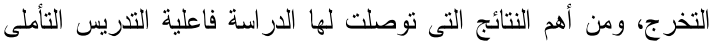

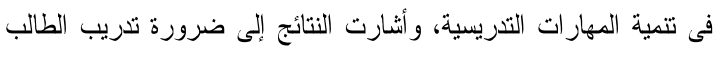
المعلم على مهار ات التفكير التأملى أثناء فترة التدريب العطلية. 
الاستطلاع بين تلاميذ معلمى الأداء المرتفع وتلاميذ معلى الأداء المنخفض

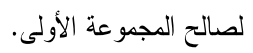

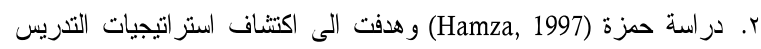

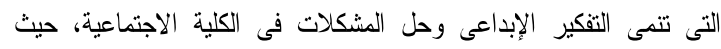

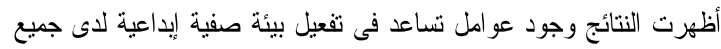

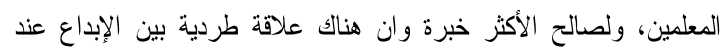

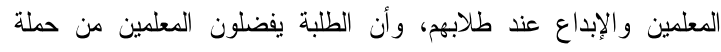

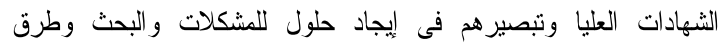
الإبداع.

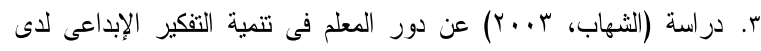

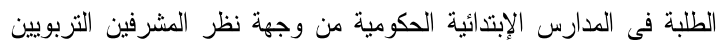

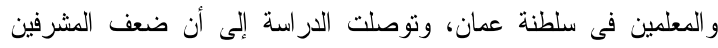

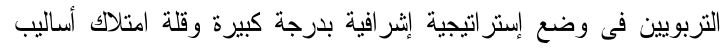

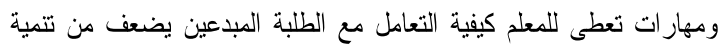

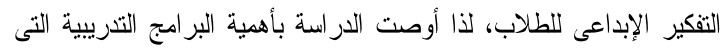

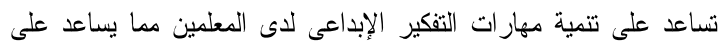
تكوين تلك المهارة لدى الطلاب.

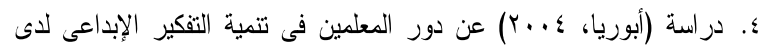

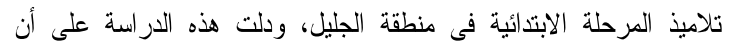

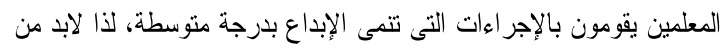

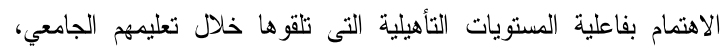

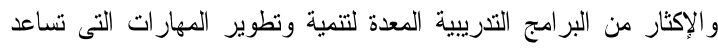

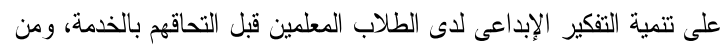

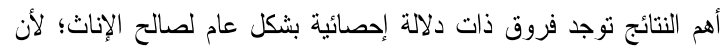

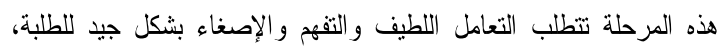
و هذه الصفات تتوفر فى الإناث أكثر مما هى عليه عند الذكور.

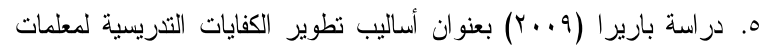

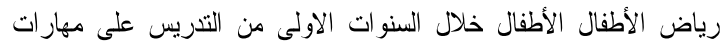

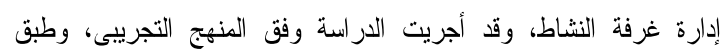

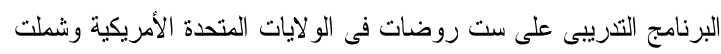

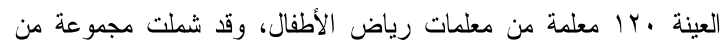

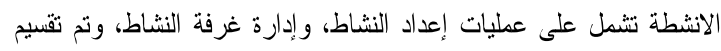

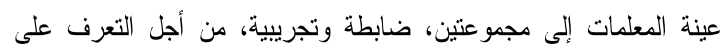

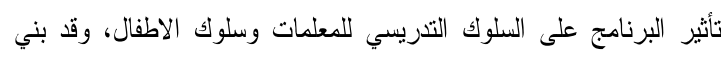
البرنامج على أسس أهمها: تدريب المعلمات بالتعلم عن طريق الممارسة

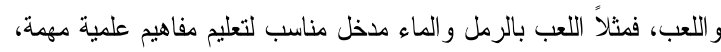
يكتسبها الطفل به المعرفة الحسية، فهم يعطلون ويخطئون ويكررون الخطأ وتوصلت الدراسة الى عدد من النتائج من أهمها وجود فروق دالة إحصائياً

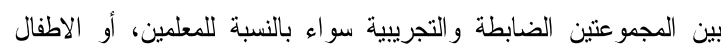

لكالح المجموعة التجريبية.

التعقيب على الدر اسات السابقة:

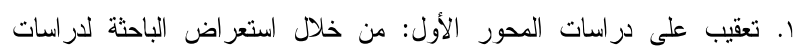

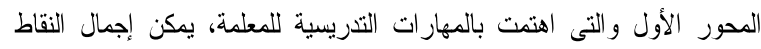

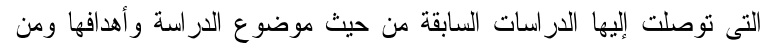

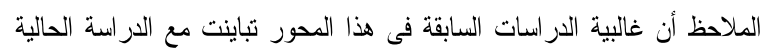

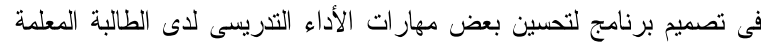

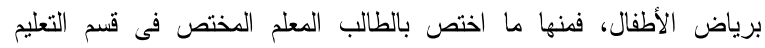

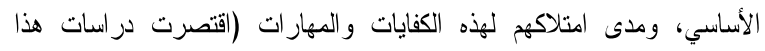

لجميع الكفايات التدريسية المقترحة، وبينت الدراسة أن تقديرات الكفايات

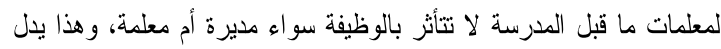

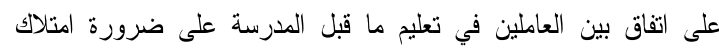

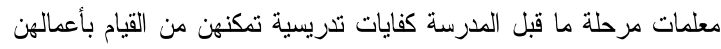

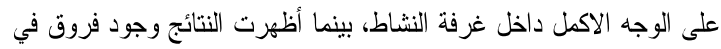

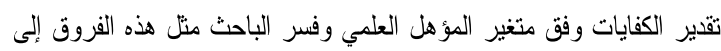

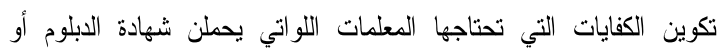

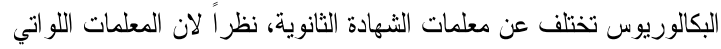
يحملن شهادة الثانوية العامة يعتبرن أن التدريس في مرحلة ما قبل المدرسة لا يتطلب معلمة مؤهلة تأهيلاً عالياً.

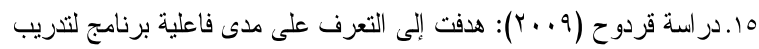

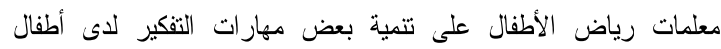

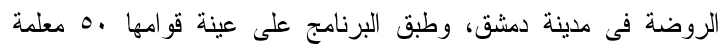

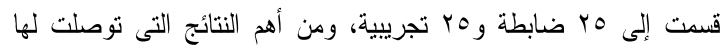

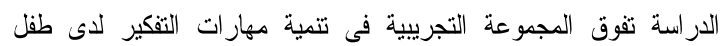
الروضة حيث ظهرث فروق واضحة بين المجموعة الضابطة والتجريبية

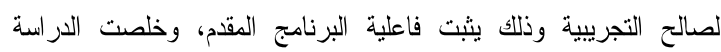
بمقترح يفيد بضرورة تدريب معلمات رياض الأطفال على الطرق الحديثة لئة

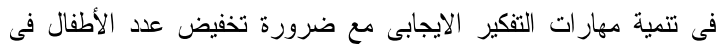
فصول الروضات.

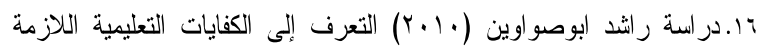
للطلبة المعلمين، تخصص معلم صف فى كلية التربية بجامعة الأزهر بغزة من وجهة نظرهم فى ضوء احتياجاتهم التدريبية، وقد استخدم الباحث المنهج

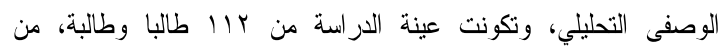

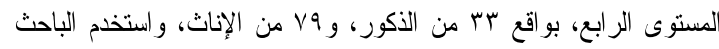

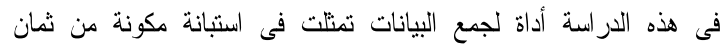

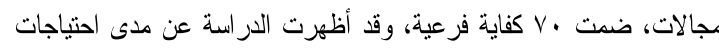

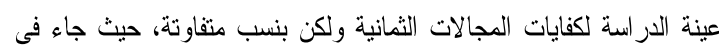

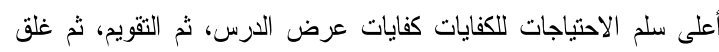

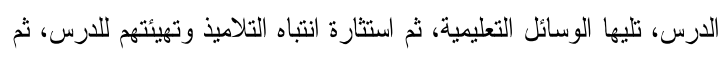

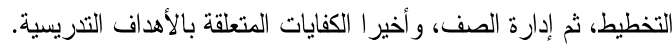

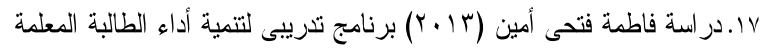

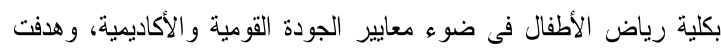

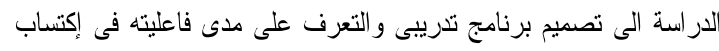

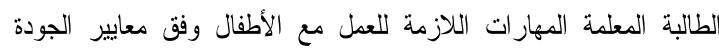

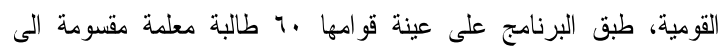

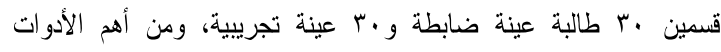

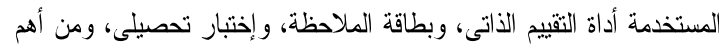

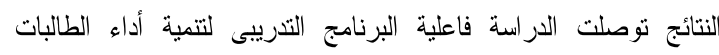

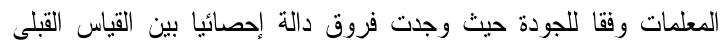

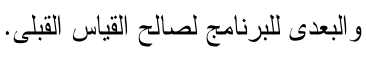

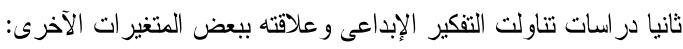

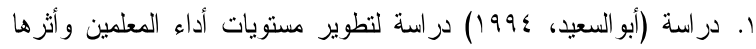

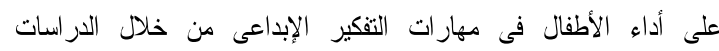

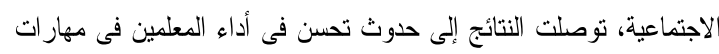

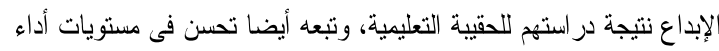
الطفل لمهارات الإبداع نتيجة تحسن مستويات أداء معلميهح فى المهارات

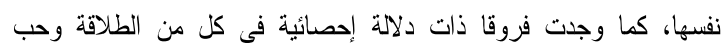


المجموعتين (الضابطة، التجريبية)، والقياسين (القبلى و البعدى) لكل من المجموعتين

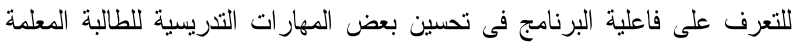

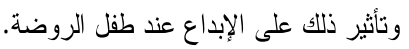

عينة اللار السة:

1. العينة الاستطلاعية: قامت الباحثة بنطبيق المقياس على عينة إستطلاعية قو امها

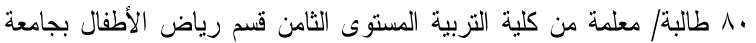

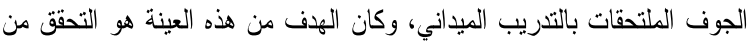

الخصائص السيكومترية لأدو ات الدراسة.

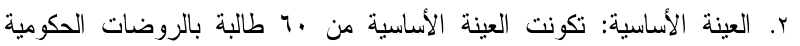

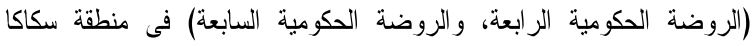

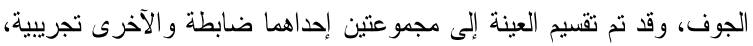

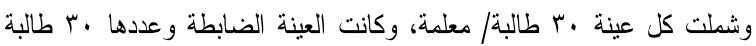

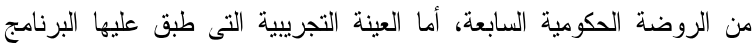

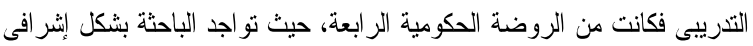

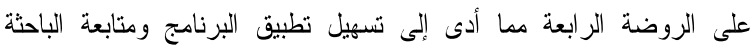

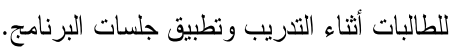

وقد قامت الباحثة بتحقيق التكافؤ بين المجموعتين فى ضو هـ الإعتبار ات الآتية: 1. إختيار العينة من تخصص واحد (رياض الأطفال). r. ايعهن من طالبات التدريب الميدانى بالمستوى الثامن.

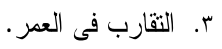

ع. التقارب فى مستوى المهار ات التدريسية. وتوضح الجداول الثالية تجانس المجموعتين التجريبية والضابطة قبل نطبيق

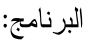
I العمر : وللتحقق من ذلك استخدمت الباحثة اختبار (ت) للعينات المستقلة، ويمكن

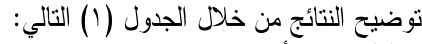
جدول (1) يوضح الأعداد و المتوسطات والانحر افات المعيارية وقيمة (ت) ودلالتها فى العمر لاى الدي

\begin{tabular}{|c|c|c|c|c|c|}
\hline \multicolumn{6}{|c|}{ وعة التجرييية و الد } \\
\hline مستوى الدلالة & قيمة (ت) & الالانحرات & المسابو سط & العدد & المجمو عة \\
\hline \multirow{2}{*}{ غير دالة } & \multirow{2}{*}{. r. } & $1, \Gamma$. & 19,9 . & $r$. & الضابطة \\
\hline & & $1, Y_{4}$ & $r \cdot, \cdot r$ & $r$. & التجرييية \\
\hline
\end{tabular}

يتضح من الجدول السابق عدم وجود فروق ذات دلالة إحصائية بين طالبات

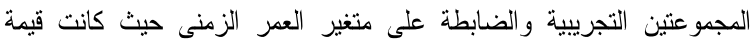

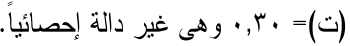
I مقياس مستوى المهارات التنريسية: قامت الباحثة بالمجانسة بين طالبات

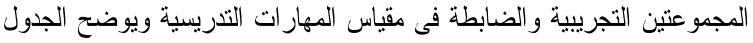

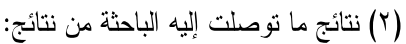

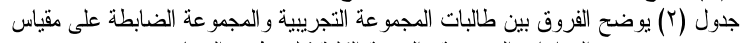

\begin{tabular}{|c|c|c|c|c|c|c|}
\hline مستوى & المحسوبة & المعياري & الحسابى سط & ن & المجمو عة | & البعد \\
\hline \multirow{2}{*}{ إخبائيا } & \multirow{2}{*}{ •, } & $r, Y$. & $\mid V, T \pi$ & $r$. & ضابطة & \multirow{2}{*}{ تهيئة الدرسق الأطفــال } \\
\hline & & r.1. & $\mid V, \varepsilon V$ & $r$. & تجريبية & \\
\hline \multirow{2}{*}{ إحصائيا } & \multirow{2}{*}{$\cdot, r)$} & $r, r$ & $\mid V, Y T$ & $r$. & ضابطة & \multirow{2}{*}{ مهارة التخطيط للارس } \\
\hline & & 1,70 & $\mid V, r T$ & $r$. & تجريبية & \\
\hline \multirow{2}{*}{ غير دالة } & \multirow{2}{*}{ י } & 1,10 & $17, \mathrm{~V}$. & $\mu$. & ضابطة & \multirow{2}{*}{ مهارة تنفيذ الدرس } \\
\hline & & $1, r V$ & $17,4 \pi$ & $r$. & تجريبية & \\
\hline \multirow{2}{*}{ غ غير دالة } & \multirow{2}{*}{$\cdot, 199$} & $1,1$. & $10, r$. & $r$. & ضابطة & \multirow{2}{*}{ مهارة تثييم الدرس } \\
\hline & & $1,1 \mathrm{~V}$ & $10,2 \mu$ & $r$. & تجريبية & \\
\hline \multirow{2}{*}{ إخيائيا } & \multirow{2}{*}{$\cdot, .9$} & $\varepsilon, Y_{O}$ & $M, V Y$ & $r$. & ضابطة & \multirow{2}{*}{ الدرجة الكلية } \\
\hline & & $\varepsilon, r \mu$ & $M, A V$ & $r$. & تجريية & \\
\hline
\end{tabular}

يتضح من الجدول السابق أن جميع قيم (ت) غير دالة إحصائيا، و الذى يدل على

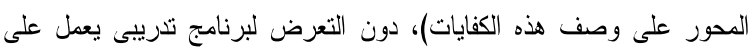

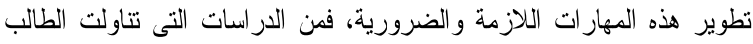

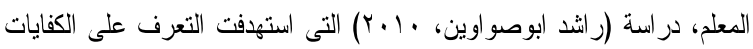
التعليمية اللازمة للطلبة المعلمين تخصص معلم الصف، ودر اسة (كوثر الثريف، 1999) التى جاءت لتبين أثر التنريب على تتمية المهار ات لدى الطلبة المعلمين.

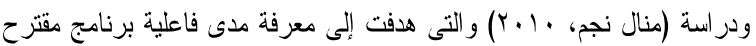

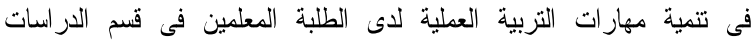

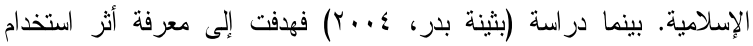

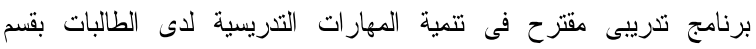

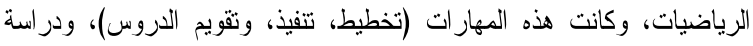
خريشة وغيرها من الدراسات السابقة هدفت الى معرفة الكفايات والمهارت

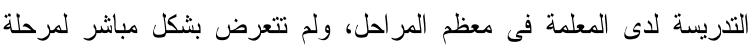

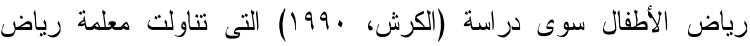

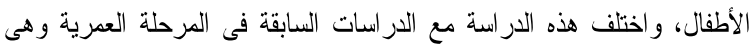

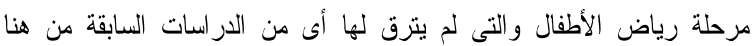

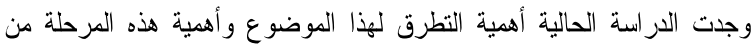

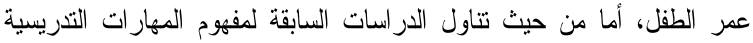
و الكفايات التدريسية فقد تباينت أهداف كل در اسة وتتوعت أغر اض وسبل تحقيقها

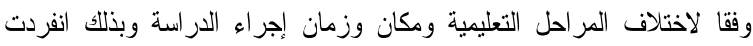

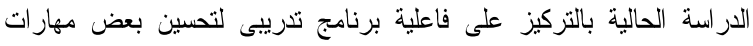

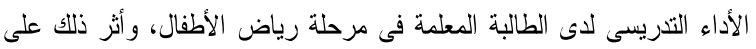

تتمية التفكير الإبداعى للى طفل الروضة.

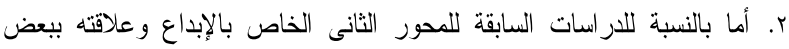

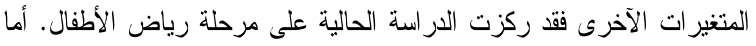

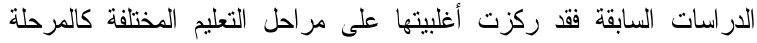

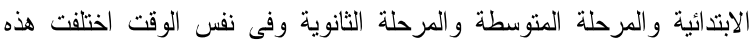

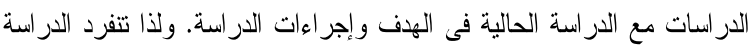

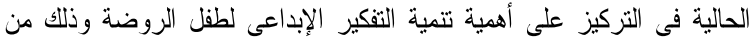

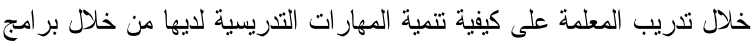

تدريبية.

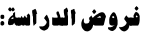

1. الفرض الأول: نوجد فروق دالة إحصائيا بين متوسطات درجات طالبات المجموعتين التجريبية والضابطة فى التطبيق البعدى على مقياس المهارات الترريسية لصالح المجموعة التجريبية. r. الفرض الثاني: يوجد فرق دال إحصائيا بين متوسطى درجات الطالبات فى لئي

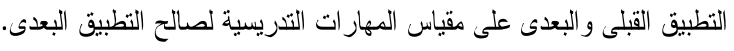

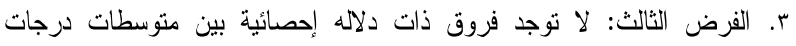
طالبات المجموعة التجريبية للقياسيين البعدى التتبعى على مقياس المهارات

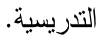

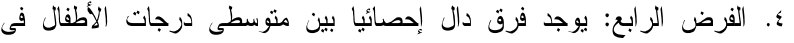
التطبيق القبلى و البعدى على مقياس إبداع الطفل لصالح التطبيق البعدى.

\section{إجراءات الدراسة}

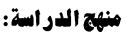

تستخدم الدراسة المنهج التجريبى وذلك من خلال تطبيق برنامج تدريبى على المي

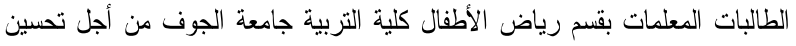

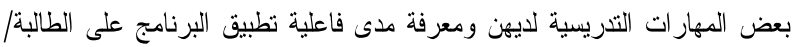

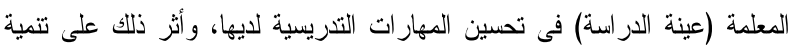
التفكير الإبداعى لدى طفل الروضة، واعتمدت الباحثة على المنهج التجريبى ذى لى 
ا.,..، و الذى يؤكد الاتساق الداخلى للمقياس، كما تـ حساب الارتباط بين

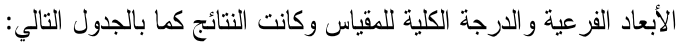

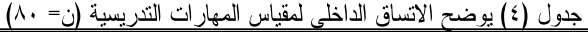

\begin{tabular}{|c|c|}
\hline معامل الارتباط & 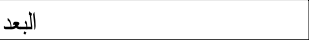 \\
\hline$\star^{\star \star},, \wedge \mathrm{V}$ & مهارة استقبال الأطفال وتهيئة الدرس \\
\hline$\star \star,, \Lambda \Lambda$ & مهارة التخطيط للارس \\
\hline$\star \star \cdot, \wedge i$ & مهارة تتفيذ الدرس \\
\hline${ }^{\star \star}, \Delta, \Delta$ & مهارة تقييج الدرس \\
\hline
\end{tabular}

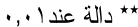

r. صدق المقارنة الطرفية (الصدق التميزى): والصدق التميزى بقصد به به بـابه

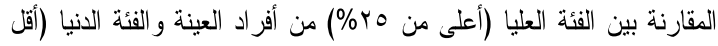

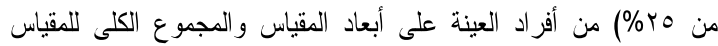

و الجدول التالى يوضح هذه المقارنة:

جدول (؟) الصدق التميزى بين أفراد العينة في أبعاد مقياس المهار ات التدريسية

\begin{tabular}{|c|c|c|c|c|c|c|}
\hline مستوى & قاتمة & الالمعراف & الحسابي المي & العدد & المجموعة & أبعاد المقياس \\
\hline \multirow{2}{*}{ |مستوى ال.,. } & \multirow{2}{*}{$9, \S 1$} & r, ז & $1 \leqslant, \wedge$. & r. & الفئة الدنبا & \multirow{2}{*}{ وتهيئة الدرسبال الأطفال } \\
\hline & & r, 10 & $r_{1, \leqslant \Lambda}$ & $r$. & الفئة العلبيا & \\
\hline \multirow{2}{*}{ 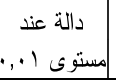 } & \multirow{2}{*}{$T, \varepsilon Y$} & $r, \pi r$ & $10, .$. & r. & الفئة الدنبا & \multirow{2}{*}{ مهارة التخطيط للارس } \\
\hline & & $r, .0$ & $r 1, \cdot \wedge$ & r. & الفئة العلبا & \\
\hline \multirow{2}{*}{ |مستوى الـ بـ. } & \multirow{2}{*}{$1 \cdot, 1 \leqslant$} & Y,19 & $1 r, \pi$. & r. & الفئة الدنبا & \multirow{2}{*}{ مهارة تتفيذ الدرس } \\
\hline & & $r, \leqslant T$ & $r \cdot, r$. & $r$. & الفئة العلبا & \\
\hline \multirow{2}{*}{ مستوى 1الة عند.. } & \multirow{2}{*}{$11, \leq 4$} & $r, \varepsilon)$ & $1 \varepsilon, \cdot \varepsilon$ & $r$. & الفئة الانيا & \multirow{2}{*}{ مهارة تقييم الدرس } \\
\hline & & $r, Y Y$ & $r \mu, \varepsilon \leqslant$ & r. & الفئة العلبيا & \\
\hline \multirow{2}{*}{ |مستوى 1الة عـ., } & \multirow{2}{*}{$17, \leqslant \mathrm{~V}$} & ד, ^ & oV, $\leftleftarrows \xi$ & r. & الفئة الدنيا & \multirow{2}{*}{ اللارجة الكلية } \\
\hline & & 0,90 & $\Delta \pi, Y$. & r. & الفئة العليا & \\
\hline
\end{tabular}

يتضح من الجدول السابق أن جميع قيم (ت) دالة إحصائيا عند مستوى

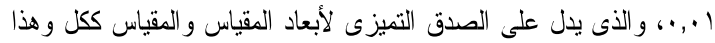

يؤكد صلاحيته للنطبيق.

وتم التأكد من ثبات المقياس بالطرق التالية: 1. طريقة التجزئة النصفية: حيث قامت الباحثة بتثسيم المقياس إلى نصفين

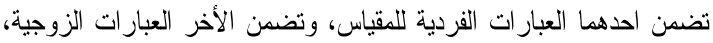

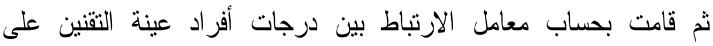

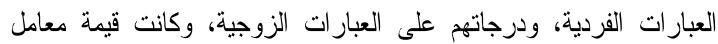
التجزئة النصفية معامل سبيرمان براون لمهارة إستقبال الأطفال وتهيئة

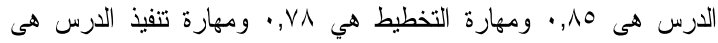

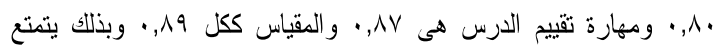

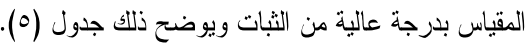

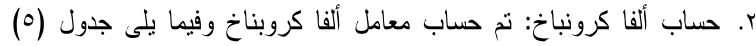

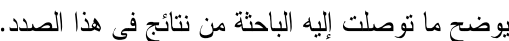
جدول (0) يوضح ثبات مقياس المهار الثات الندريسية بطريقة ألفا كرونباخ وطريقة التجزئة النصفية

\begin{tabular}{|c|c|c|}
\hline (سبيرمان براون) & معامل ألفا كرونباخ & البعد \\
\hline$\cdot, 10$ & $\cdot, \mathrm{AV}$ & مهارة استثبال الأطفال وتهيئة الدرس \\
\hline$\cdot, \mathrm{VA}$ & $\cdot, \Lambda 1$ & مهارة التخطيط للارس \\
\hline$\cdot, \wedge$. & $\cdot, \wedge \leqslant$ & مهارة تتفيذ الدرس \\
\hline$\cdot, A V$ & $\cdot, \Lambda$ & مهارة ثقييم الدرس \\
\hline$\cdot, \wedge 9$ & 童, & المقياس ككل \\
\hline
\end{tabular}

يتضح من الجدول السابق أن جميع معاملات الثبات مرتفعة و الذى يؤكد ثبات مقياس المهار ات التدريسية.

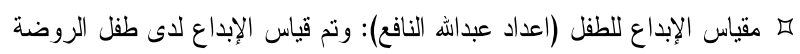

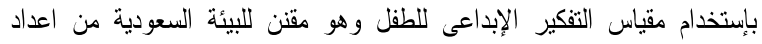
عبداله النافع، وقد قامت الباحثة بقياس الثبات لمقياس إبداع الطفل بطريقة ألفا
تجانس المجموعة التجريبية والمجموعة الضابطة على مقياس المهار ات التّريسية

قبل تطبيق البرنامج.

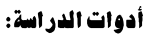

口 مقياس المهارات التدريسية (إعداد الباحثة): قامت الباحثة بإعداد مقياس المهارات

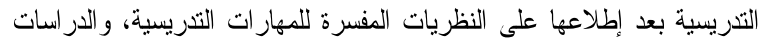

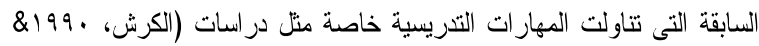

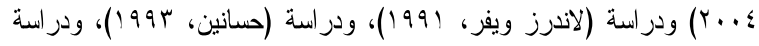

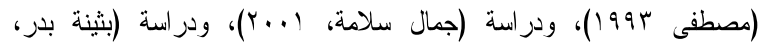

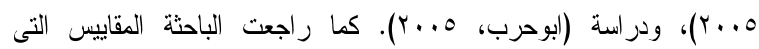
استخدمت فى هذه الدر اسات لقياس المهار ات التدريسية.

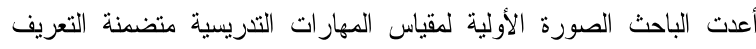

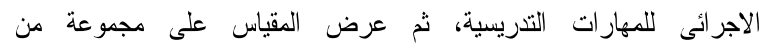
المتخصصين فى مجال الصحة النفسية ورياض الأطفال وعلم النفس، والمناهج الإبداء الر أي.

وتكون المقياس فى صورته النهائية من ·ـ عبارة موزعة على ؛ أبعاد فرعية

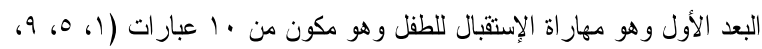

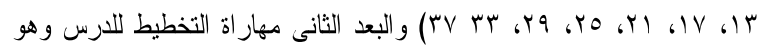

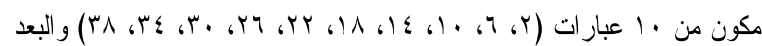

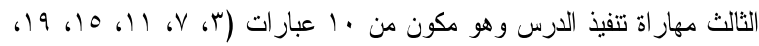
بr

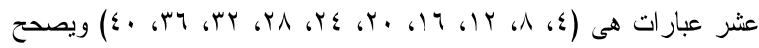

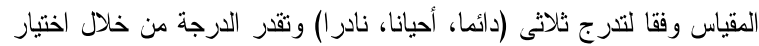

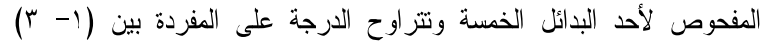

درجات طبقا لاتجاه قياس المفردة. وتم التحقق من صدق المقياس بالطرق التالية:

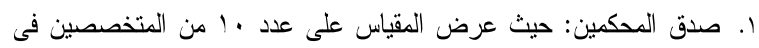

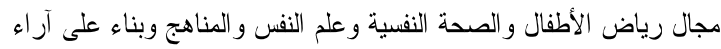

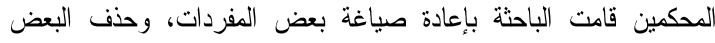

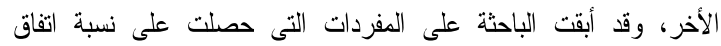

(\%)... - \% .) r. صدق الاتساق الداخلي: تم حساب معامل الارتباط بين درجة كل عبارة مع درجة البعد الذى تتنمى إليه وكذلك معامل الارتباط بين الأبعاد و الدرجة

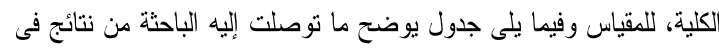

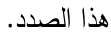

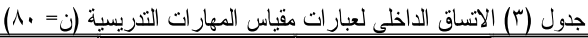

\begin{tabular}{|c|c|c|c|c|c|c|c|}
\hline \multicolumn{2}{|c|}{ مهارة تقييم الدرس } & \multicolumn{2}{|c|}{ مهارة تنفيذ الارس } & \multicolumn{2}{|c|}{ مهارة التخطيط للارس } & \multicolumn{2}{|c|}{ مهارة استقبال الأطفال } \\
\hline الارتباط & ققم العبارة & الارتباط & رقم العبارة & الارتباط & رقم العبارة & الارتباط & رقم العبارة \\
\hline${ }^{\star \star} \cdot, \pi$ & ؛ & ${ }^{\star \star}{ }_{0}, \varepsilon \wedge$ & $r$ & ${ }^{\star \star},, V V$ & $r$ & ${ }^{\star \star},, v$, & 1 \\
\hline$\star^{\star \star},, \wedge \uparrow$ & $\Lambda$ & $\star \star \star, 0 \Lambda$ & $\mathrm{V}$ & ${ }^{\star \star}, 09$ & 7 & $\star \star \star, V$. & 0 \\
\hline${ }^{\star \star},, i \Lambda$ & Ir & ${ }^{\star \star},, \leqslant \Lambda$ & 11 & ${ }^{\star \star},, v$. & 1. & ${ }^{\star \star},, v \varepsilon$ & 9 \\
\hline$\star \star, \vee, v$. & 17 & $\star \star ., O r$ & 10 & ${ }^{\star \star} \cdot, \leqslant 9$ & $1 \leq$ & $\star \star,, \vee 9$ & $1 \pi$ \\
\hline$\star \star,, i$ & $r$. & $\star \star,, 0$. & 19 & ${ }^{\star \star}, 07$ & 11 & ${ }^{\star \star} \cdot, \pi$ & IV \\
\hline$\star^{\star \star}, 0$. & $r \varepsilon$ & ${ }^{\star \star}, \wedge \varepsilon$ & r & ${ }^{\star \star},, 01$ & rY & ${ }^{\star \star},, 70$ & rI \\
\hline$\star^{\star},, \leqslant 9$ & YA & ${ }^{\star \star},, V_{1}$ & TV & $\star \star, \pi q$ & YT & $\star_{\star}^{\star \star},, v$. & ro \\
\hline${ }^{\star \star}{ }_{,},\{0$ & rT & ${ }^{\star \star},, v \wedge$ & $r$ & ${ }^{\star \star},, \pi 1$ & $r$. & $\star^{\star \star},, \circ$. & rq \\
\hline${ }^{\star \star} \cdot, V Y$ & $m 4$ & ${ }^{\star \star} \cdot, \lambda 4$ & ro & ${ }^{\star \star} \cdot, \eta 11$ & $r \leq$ & $\star \star \star, n)$ & r \\
\hline$\star^{\star \star},, 0 \mathrm{~V}$ & ؛. & $\star \star ., 79$ & rq & $\star \star \star, \pi r$ & rی & ${ }^{\star \star} \cdot, v V$ & $r v$ \\
\hline
\end{tabular}

يتضح من جدول (rّ) أن جميع مفردات أبعاد المقياس كانت دالة عند مستوى لُ 
(جيهان جودة 0 . . ب)، وبرنامج تتمية المهار ات الحياتية و أثره فى تجويد

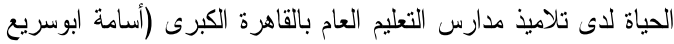

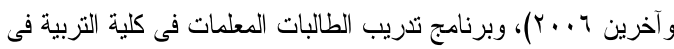
جامعة الملك فيصل على بعض مهار ات صوغ الأهداف التعليمية و إعداد

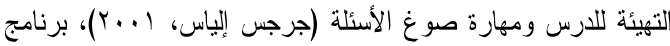

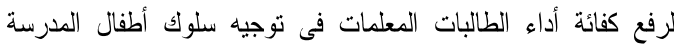

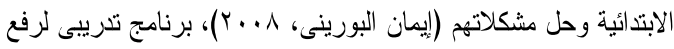

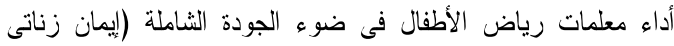

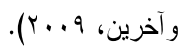

وقد استفادت الباحثة من الاطلاع على هذه البرامج فى تحديد محتوى

$$
\text { البرنامج و أنشطنه. }
$$

r. أسس بناء البرنامج: تم تصميم البرنامج للطالبة/ المعلمة بكلية التربية جامعة

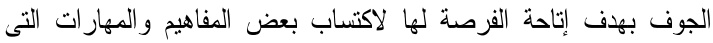

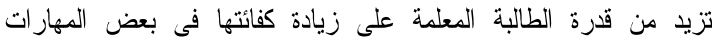

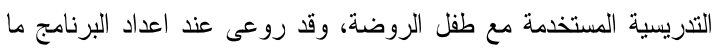

أ. أن يتسم البرنامج بالمرونة، حيث يستجيب لمتطلبات الموقف أو النثاط الذى تعرضه الجلسة مع الالتز ام بالخطوط العريضة للجلسة.

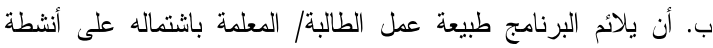
ملائمة لو اقع الطفل وبيئة الروضة.

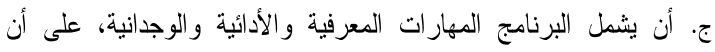
ير اعى التركيز على دهار ات استقبال الطفل و التخطيط للارس وتثونيه. د. أن لا يقتصر هدف البرنامج على تزويد الطالبة بالمعلومات النظرية

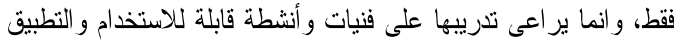

$$
\text { العطلى فى الروضة. }
$$
ه. أن يراعى البرنامج الفروق الفردية بين الطالبات/ المعلمات.

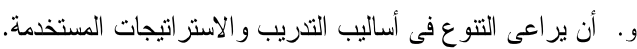
ز. أن ير اعى البرنامج التسلسل المنطقى فى جلساته حيث تكون منتالية وكل جلسة تهيئ وتمهد للجلسة التالية لها. ؛. أساليب تم استخدامها فى البرنامج: أ. أ. المحاضرة و المناقشة. ب. الدروس النموذجية. ج. ورش عمل.

د. تكليف المتدربات ببعض الو اجبات المنزلية.

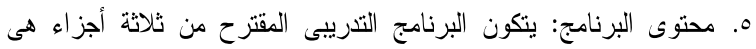

(الجزء النظري- الدروس النموذجية- ورش العمل - الو اجبات المنزلية). آ. محتوى البرنامج التنريبي: يقصد بالمحتوى مجموعة المهار ات و الأنشطة

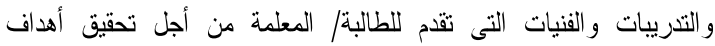
البرنامج وقد روعى عند اختيار محتوى البرنامج مايلي:

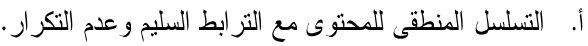

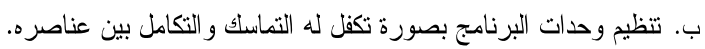

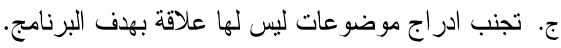

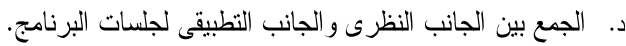
ه. أن يقام البرنامج على اعتبار الاحتياجات التنريبية هى الركيزة الأساسية.

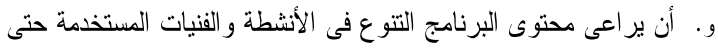

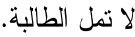
V . محتوى جلسات البرنامج: تم تحديد محتوى البرنامج بناءا على الكتابات

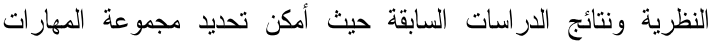

كرونباخ وطريقة التجزئة النصفية (تصحيح سبيرمان براون)، ويوضح جدول

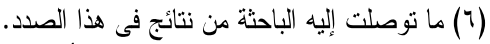

جلول (T) يوضح ثبات مقياس إبداع الطفل بطريقة ألفا كرونباخ وطريقة التجزئة النصفية معامل ألفا كرونباخ باتخ $\cdot, \mathrm{VI}$ $\cdot, \lambda$

يتضح من الجدول السابق أن معاملى الثبات مرتنعين و الذى يؤكد ثبات مقياس إبداع الطفل.

I م برنامج تدريبى لتحسين بعض المهارات التدريسية لدى الطالبة/ المعلمة بجامعة الجوف و أثزه على التفكير الإبداعى لطفل الروضة (إعداد الباحثة):

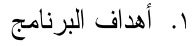

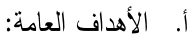

1. يهذف البرنامج إلى تدريب الطالبات المعلمات على المهارات

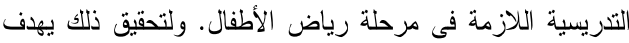

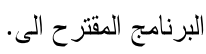

r. إكساب المتدربات مهار ات تدريسية تثزى الموقف التعليمى لطفل

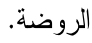

r. تبصير المتدربات ببعض نظريات تعليم وتعلم التفكير الإبداعى لطفل

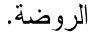

؛. تبصير المتدربات بعض الاستراتيجيات والمداخل التدريسية المعاصرة فى تدريس رياض الأطفال.

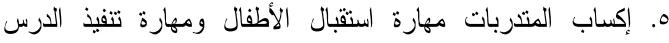
وتحليل محتوى الدرس وتثقيمه.

1. إكساب المتدربات مهارة صياغة الأهداف فى صورة إجر ائية.

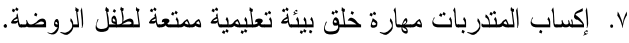

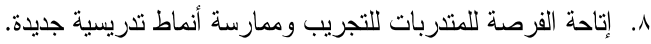

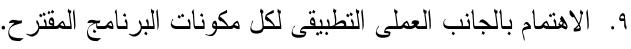
ب. الأهداف الخاصة للبرنامج: ا. ـ دراسة فاعلية البرنامج المقترح في تتمية بعض المهارجية المارات التدريسية الكلازمة للطالبة/ المعلمة. r. تتمية قدرة الطالبة/ المعلمة على استخدام مهارات التدريس بكفائه وتميز. r. إكساب الطالبات/ المعلمات المهارات التّريسية اللازمة لهن

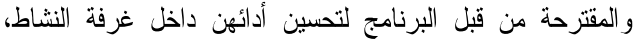

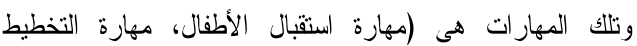
لللارس، مهارة تنفيذ الدرس، مهارة تثويم الدرس).

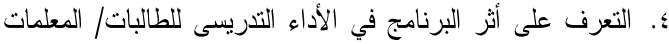

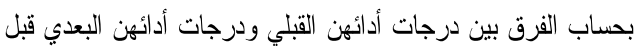

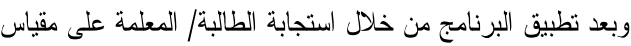

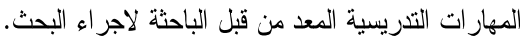

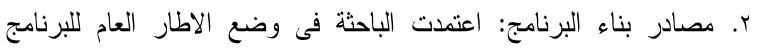

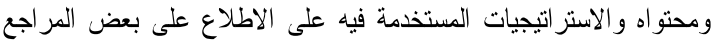
و الدر اسات العربية و الأجنبية التى تتاولت:

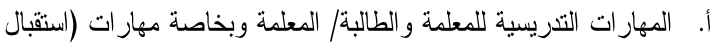
الأطفال - والتخطيط للارس- تنفيذ الدرس- تثويم الدرس) برنامج لتحسين بعض المهارات التدريسية لمعلمي التربية الرياضية بالمرحلة

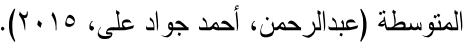

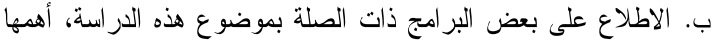

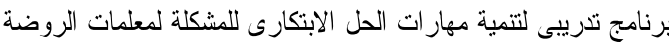


توجد فروق ذات دلالة إحصائية بين المجموعة الضابطة والمجموعة التجرييية

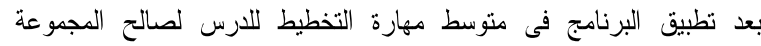

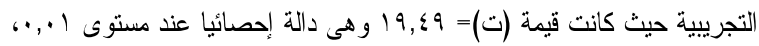
ويتضح من الجدول السابق أنه توجد فروق ذات دلالة إحصائية بين المجموعة

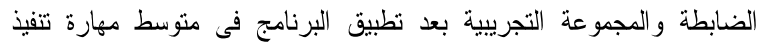

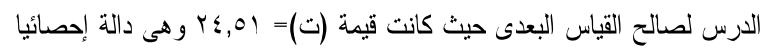

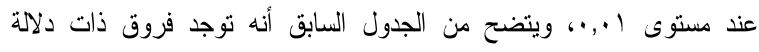

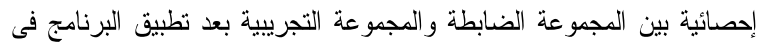

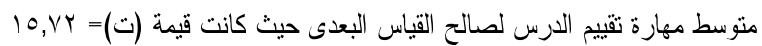

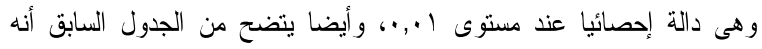
توجد فروق ذات دلالة إحصائية بين المجموعة الضابطة و المجموعة التجريبية

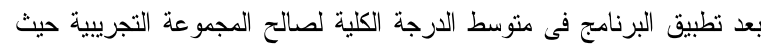

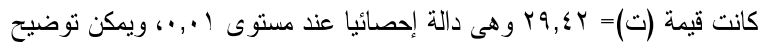
هذه النتيجة من خلال الثكل التالى:

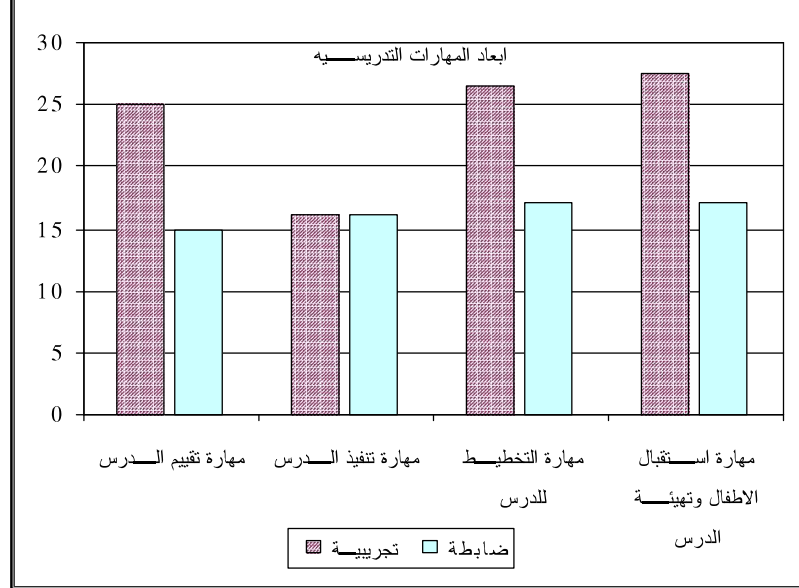

شكل (1) المتوسطات الحسابية للمجموعة التجريبية والمجموعة الضابطة فى القياس البعدى على

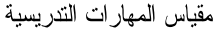

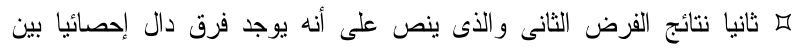

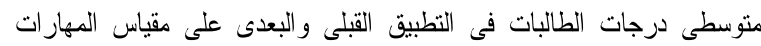

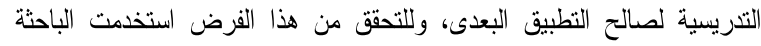
اختبار (ت) للعينات المرتبطة ويمكن عرض ما توصلت إليه الباحثة من نتائج من لن

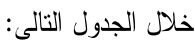

جنول (^) يوضح الأعداد و المتو سطات والانحر افات المعيارية وقيمة (ت) ودلالتها فى على مقياس

\begin{tabular}{|c|c|c|c|c|c|c|c|c|}
\hline | الثتأثير & مربع & | مستوى الدلالة & (ت) & $\varepsilon$ & ? & ن ن & القياس & البعد \\
\hline \multirow{2}{*}{ كبير } & \multirow{2}{*}{$\bullet, \wedge 9$} & \multirow{2}{*}{ | عند إ.,. } & \multirow{2}{*}{ rr,vq } & r,1. & $\mid V, \varepsilon V$ & $r$. & قبلى & \multirow{2}{*}{ وتهيئة الدرسبال الأطفال } \\
\hline & & & & $1, v$. & $r \Lambda, 1 T$ & $r$. & بعدى & \\
\hline \multirow{2}{*}{ كبير } & \multirow{2}{*}{ • } & \multirow{2}{*}{ عند ا.,., دائيا } & \multirow{2}{*}{$\mathrm{r}, \mathrm{QV}$} & 1,10 & | & $r$. & قبلى & \multirow{2}{*}{ مهارة التخطيط للارس } \\
\hline & & & & $r, .1$ & $r Y, \varepsilon \cdot$ & $r$. & بعدى & \\
\hline \multirow{2}{*}{ 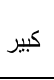 } & \multirow{2}{*}{$\cdot, 10$} & \multirow{2}{*}{ عند ا.,., الحصئيا } & \multirow{2}{*}{$r \cdot, V Y$} & $1, r V$ & $19, \pi$ & $r$. & قبلى & \multirow{2}{*}{ مهارمتيفيذ الدرس } \\
\hline & & & & $r, 11$ & $Y V, \varepsilon V$ & $r$. & بعدى & \\
\hline \multirow{2}{*}{ كبيز } & \multirow{2}{*}{$\cdot, V y$} & \multirow{2}{*}{ عند الب, إحصائيا } & \multirow{2}{*}{$I V, r \varepsilon$} & $1,1 \mathrm{~V}$ & $10, \varepsilon \pi$ & $r$. & قبلى & \multirow{2}{*}{ مهارة تثيبي الدرس } \\
\hline & & & & $\begin{array}{ll}, 44 \\
, 4\end{array}$ & ro,rr & $\mu$. & بعدى & \\
\hline \multirow{2}{*}{ كبير } & \multirow{2}{*}{$\cdot, 91$} & \multirow{2}{*}{ عند ا.,., دائيا } & \multirow{2}{*}{$\Lambda 1, \Lambda Y$} & $\varepsilon, r^{\mu}$ & $\pi r, \lambda V$ & $r$. & قبلى & \multirow{2}{*}{ الدرجة الكلية } \\
\hline & & & & $\tau, \varepsilon \vee$ & $|1, \lambda, r \mu|$ & $r$. & بعدى & \\
\hline
\end{tabular}

يتضح من الجدول السابق أنه توجد فروق ذات دلالة إحصائية بين القياس القبلى

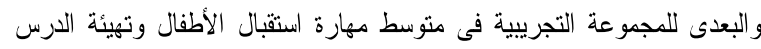

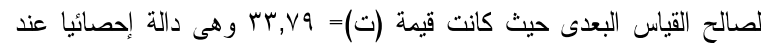
مستوى ا.,.,، كما يتضح من الجدول السابق أنه توجد فروق ذات دات دلالة إحصائية بين القياس القبلى والبعدى للمجموعة التجريبية فى متوسط مهارة
التدريسية التى يتضمنها البرنامج لتتريب الطالبة/ المعلمة عليها وهي (مهارة

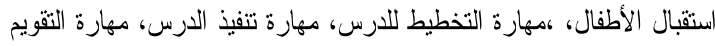

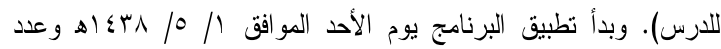

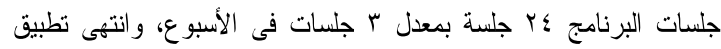

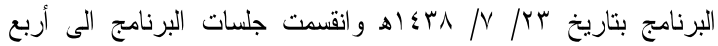
وحدات سبقتهم جلسة تمهيدية للتعارف وتوضيح وتبصير الطالبات بالبرنامج

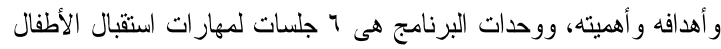

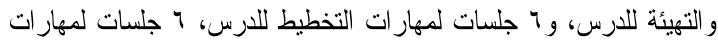

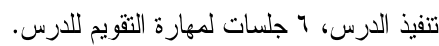

الأساليب الاحصائية:

1. استخدام اختبار (ت) للعينات المستقلة. r. استخدام اختبار (ت) للعينات المرتبطة.

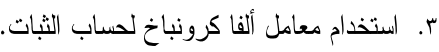
؛. التجزئة النصفية لسبيرمان بر اون لحساب الثبات. ه. استخدام معامل الارتباط لبيرسون لحساب الاتساق الداخلي.

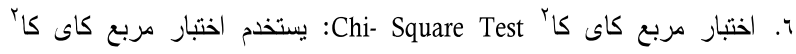

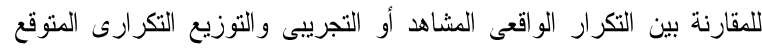

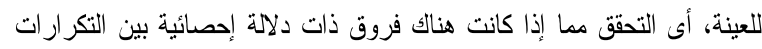

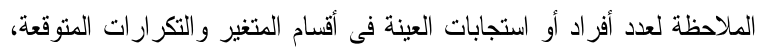

$$
\text { وتستخدم المعادلة التالية لحساب كا'r' }
$$

حيث تعبر (ك) عن التكرار الملاحظ، وتعبر ك عن التكرار النظرى (المتوقع)

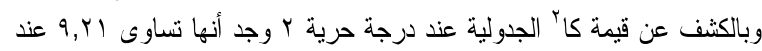

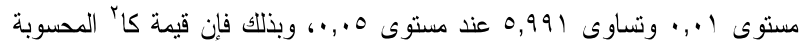
التى تقل عن 0,991 تكون غير دالة إحصائيا.

\section{نتائع الدر اسة و ومثاقشتها:} ه أو لا نتائج الفرض الأول: والذى ينص على انه توجد فروق دالة إحصائيا بين

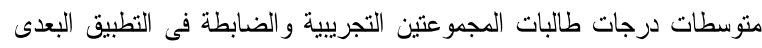

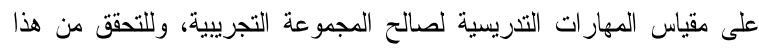
الفرض استخدمت الباحثة اختبار (ت) للعينات المستقلة ويمكن عرض ما توصلت

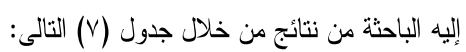

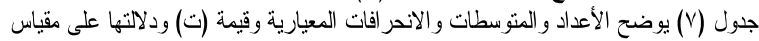

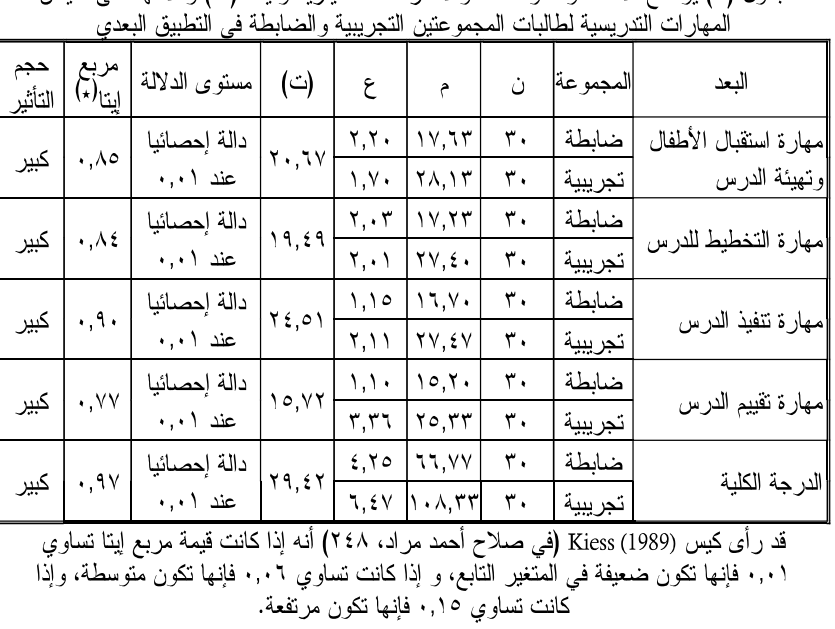

يتضح من الجدول السابق أنه توجد فروق ذات دان دلالة إحصائية بين المجموعة الضابطة والمجموعة التجريبية بعد تطبيق البرنامج فى متوسط مهارة استقبال

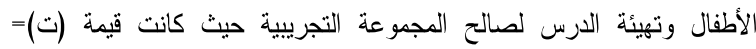

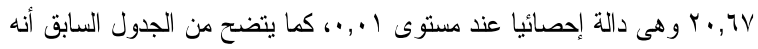




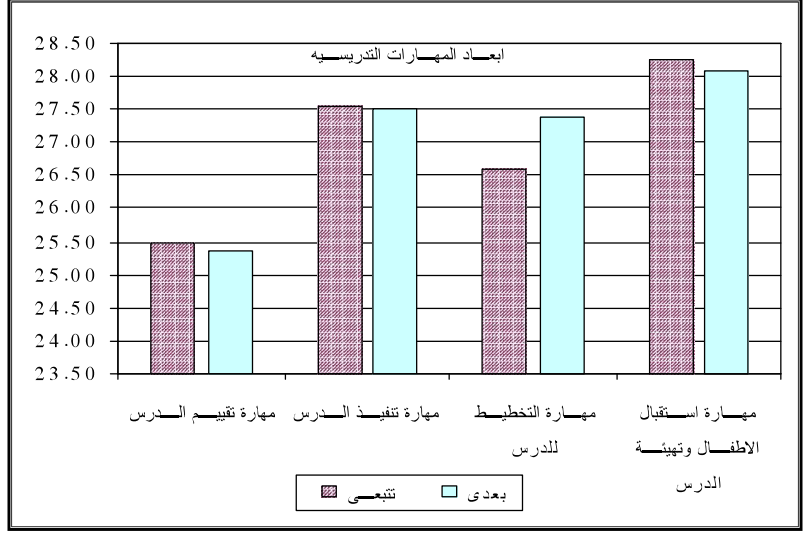

شكل (ץ) المتوسطات الحسابية للمجموعة التجريبية فى القياس البعدى و القياس التتبعى على مقياس المهارات التنريسية التيان

كـ مناقشة نتائج الفروض الثلاثة: أثنارت النتائج الى تحقق فروض الدراسة الثلاث

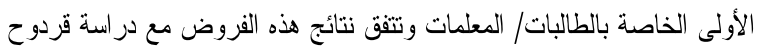

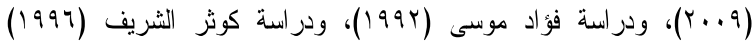

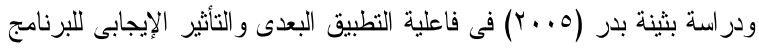

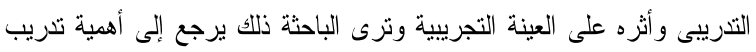

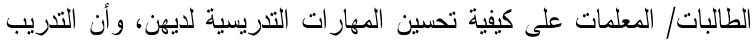

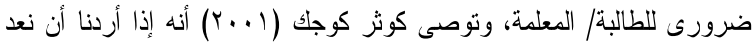

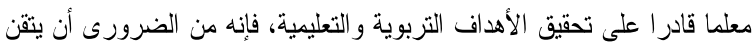
مجموعة مهار ات أدائية يتكون من مجموعها قدرته على مهارة الاستقبال وتهيئة للارس وتتفيذه و التخطيط له.

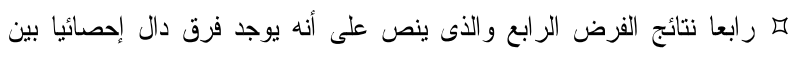

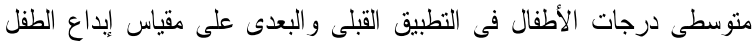

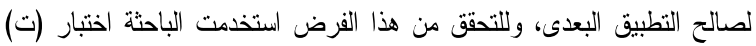

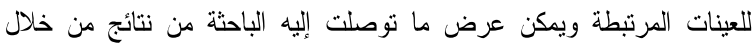

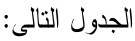
جدول ( • () يوضح الأعداد و المتوسطات و الانحر افات المعيارية وقيمة (ت) ودلالتها فى على

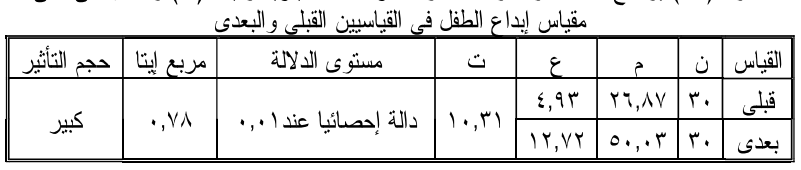

يتضح من الجدول السابق أنه توجد فروق ذات دلالة إحصائية بين القياس القبلى

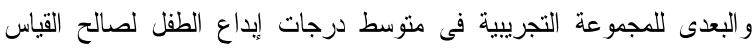

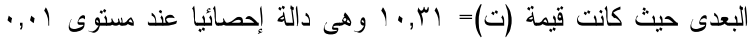
ويمكن توضيح هذه النتيجة من خلال الثكل التالى:

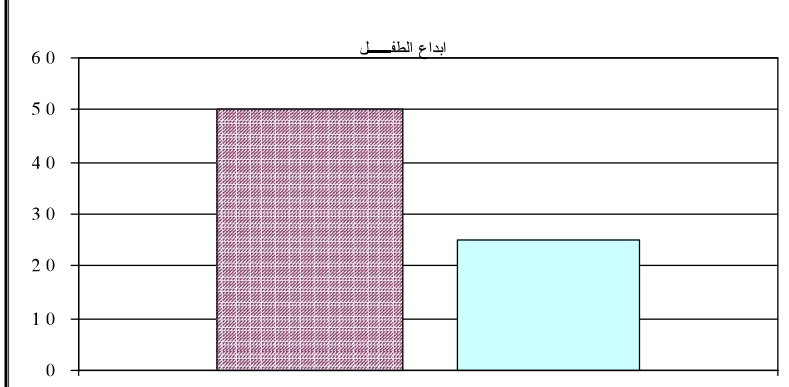

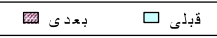

شكل (؛) المتوسطات الحسايبة لأطفال للمجموعة التجريبية فى القياس القبلى و القياس البعدى على مقياس إبداع الطقل

و هذا يدل على الاثر الايجابى الذى أحثثه البرنامج فى إبداع الطفل لدى الطالبات/

المعلمات بالمجموعة التجريبية.
التخطيط للدرس لصالح القياس البعدى حيث كانت قيمة (ت) = Y Y Y و هى دالة

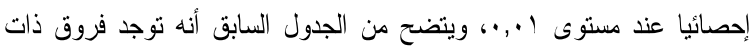

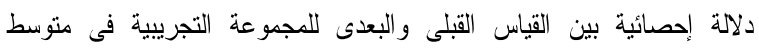

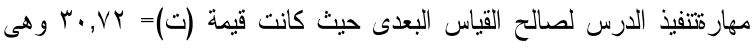

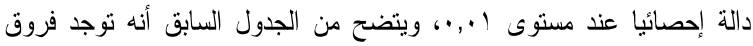

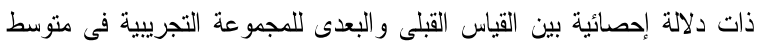

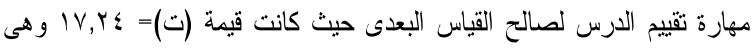

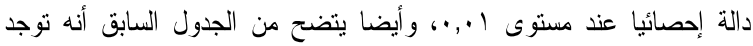
فروق ذات دلالة إحصائية بين القياس القبلى والبعدى للمجموعة التجريبية فى ولى لئي

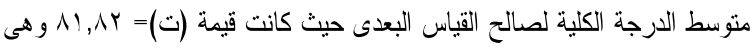

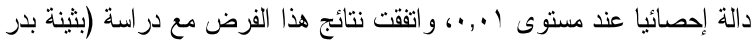

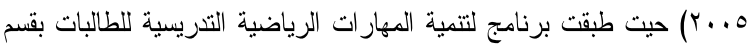

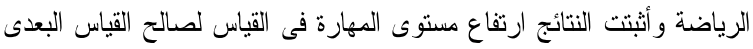
ويتقق ذلك مع الدر اسة الحالية ويمكن توضيح هذا من خلال الثكل التالى: لئي

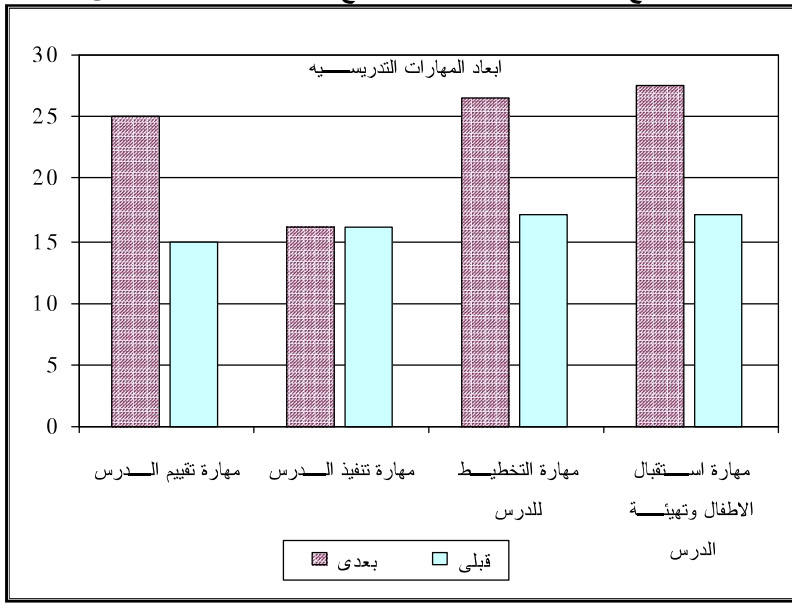

شكل (r) المتوسطات الحسابية للمجموعة التجريبية فى القياس القبلى و القياس البعدى على مقياس المهار ات التبريسية فئاس

ه ثالثا نتائج الفرض الثالث و الذى ينص على أنه لا توجد فروق ذات دلاله إحصائية

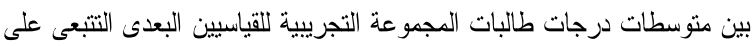
مقياس المهارات التدريسية، وللتحقق من هذا الفرض استخدمت الباحثة اختبار (ت) للعينات المرتبطة ويمكن عرض ما توصلت إليه الباحثة من نتائج من خلال لئل

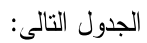
جدول (9) يوضح الفروق بين القياسيين البعدى و التتبعى فى مقياس المهارات التريسية للمجموعة

\begin{tabular}{|c|c|c|c|c|c|c|}
\hline مستوى & قيمة (ت) & الالانحر ان & الحسابي & العدد & القياس & البعد \\
\hline \multirow{2}{*}{ غير دالة } & \multirow{2}{*}{ • } & $1, \mathrm{~V}$. & $r \Lambda, I r$ & $r$. & بعدى & \multirow{2}{*}{ تهارة استقبال الأطفال } \\
\hline & & r.vo & $r \Lambda, Y Y$ & $r$. & تتبعى & \\
\hline \multirow{2}{*}{ غير دالة } & \multirow{2}{*}{$1,0 \leqslant$} & $r, \cdot 1$ & $r v, \varepsilon$. & $r$. & بعدى & \multirow{2}{*}{ مهارة التخطيط للارس } \\
\hline & & $r, \varepsilon V$ & $Y Y, V \cdot$ & $r$. & تنتعى & \\
\hline \multirow{2}{*}{ غير دالة } & \multirow{2}{*}{ • } & $r, 11$ & $r V, \varepsilon V$ & $r$. & بعدى & \multirow{2}{*}{ هارة تتفيذ الدرس } \\
\hline & & $r, \varepsilon q$ & $r v, r$ & $r$. & تتبعى & \\
\hline \multirow{2}{*}{ غير دالة } & \multirow{2}{*}{ r } & r, & ro,rr & $r$. & بعدى & \multirow{2}{*}{ مهارة تقييم الدرس } \\
\hline & & $r, r \Lambda$ & ro,or & $r$. & تنبعى & \\
\hline \multirow{2}{*}{ غير دالة } & \multirow{2}{*}{1,70} & $T, \leqslant V$ & $1 \cdot \lambda, r r$ & $r$. & بعدى & \multirow{2}{*}{ الدرجة الكلية } \\
\hline & & $8, r \varepsilon$ & $1 \cdot 1,1$. & $r$. & تنبعى & \\
\hline
\end{tabular}

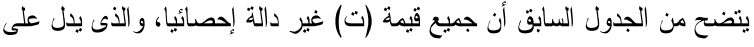

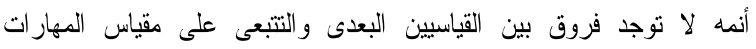
التدريسية، ويمكن توضيح هذه النتيجة من خلال الثكل التالى: 


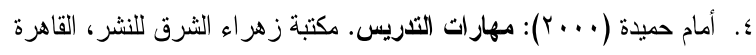

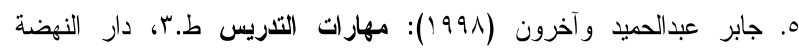
العربية، القاهرة.

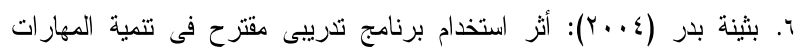

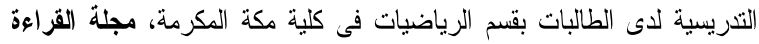

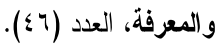

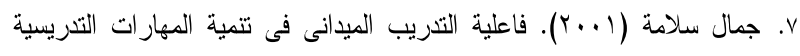

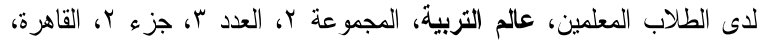

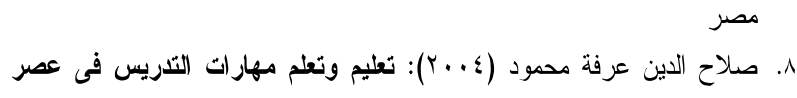
المعلومات. عالم الكتب، القاهرة.

9. عبدالعزيز عبدالوهاب البابطين (1990): الكفايات التعليمية اللازمة للطالب البرة المعلم وتقصى أهميتها وتطبيقاتها من وجهة نظره ونظر المشرف عليه فى كلية لئل

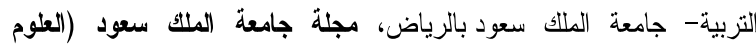

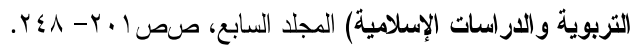

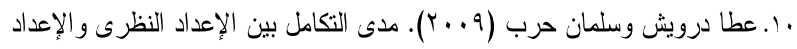

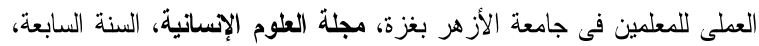

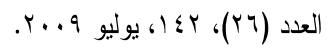

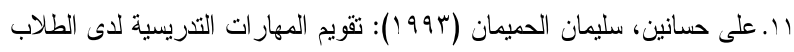

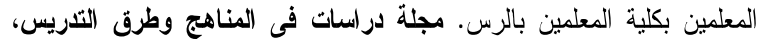
الجمعية المصرية للمناهج وطرق التنريس، ع ل1 ا، القاهرة.

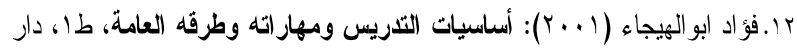

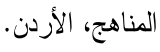

با. فؤاد موسى (Y99 (1)): فاعلية برنامج لتريب الطلاب المعلمين شعبة الرياضيات

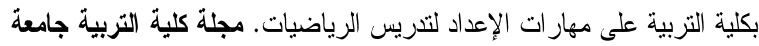
المنصورة، ع 191، المنصورة.

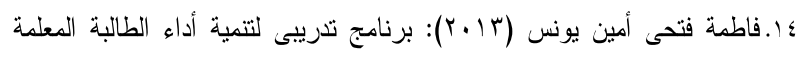

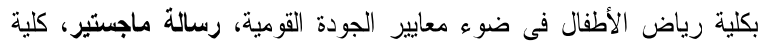

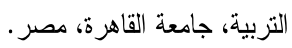

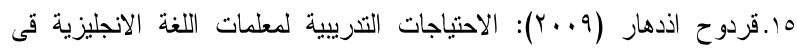
رياض الأطفال، دراسة ميدانية بدينة دمشق، رسالة ماجستير، كلية التربية،

$$
\text { جامعة دمثق }
$$

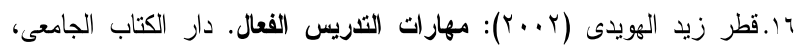

$$
\text { العين. }
$$

VI. المؤتمر القومى للتطوير (1997): إعداد المعلم وتدريبه ورعايته، الجمعية

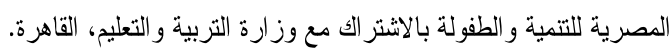

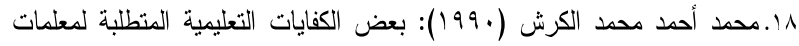

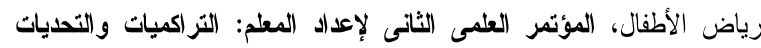

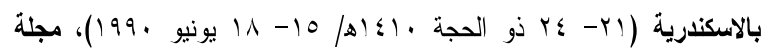
الجمعية المصرية للمناهج وطرق التدريس، المجلد الثالث.

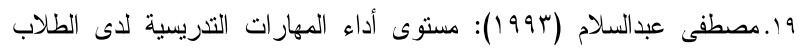
المعلمين. المؤتمر العلمى الخامس للجمعية المصرية للمناهج وطرق التكريس. r.r.r.r.

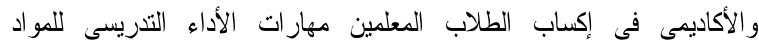

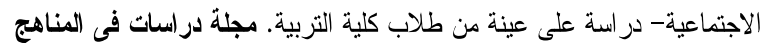

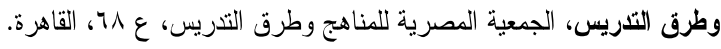

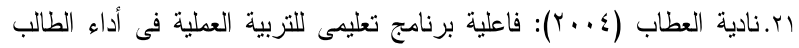

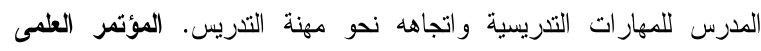

ه نتائج استمارة تقييم البرنامج: تم حساب التكرارات و النسب المئوية للطالبات على لئل

\begin{tabular}{|c|c|c|c|c|c|c|c|c|}
\hline \multirow{2}{*}{ الدلالة } & \multirow[t]{2}{*}{ K } & \multicolumn{2}{|c|}{ بدرجة بسيطة } & \multicolumn{2}{|c|}{ بدرجة متوسطة } & \multicolumn{2}{|c|}{ بدرجة كبيرة } & \multirow{2}{*}{ العبارات } \\
\hline & & $\%$ & s & $\%$ & 5 & $\%$ & ك) & \\
\hline .1 & $1 \%, \varepsilon$. & 1. & & & & אז, & 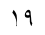 & استفدت من البرنامج \\
\hline .1 & $1, r$. & זיז, & & . & 9 & TV & $r$. & كان البرنامج شيقا وجذا \\
\hline$\cdot, \cdot 1$ & $r \cdot, r$. & r r r r r & 1 & $17, \mathrm{iv}$ & 0 & $A_{1}, \cdots$ & $r \varepsilon$ & r. أهداف البرنــامج كانـــت \\
\hline .1 & $r 1, \lambda$. & .. & $r$ & TV & o & VT, ru & rr & ؛. ت استخدام البرنامج أســاليب \\
\hline. .1 & rr,,. & $i, Y \mathrm{YV}$ & r & $r_{\cdot,}, \cdot$ & 9 & VT, & rr & 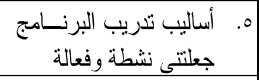 \\
\hline$\cdot, \cdot 1$ & $19, \lambda$. & $x, 4 \mathrm{~V}$ & r & rY, iv & $\wedge$ & $47,4 \mathrm{~V}$ & r. & I. ـ ساهم البرنامج فى إتــراء \\
\hline,,+1 & $r q, \%$ & iv & r & "זr & ؛ & $A_{\cdot}, \cdot \cdot$ & r६ & 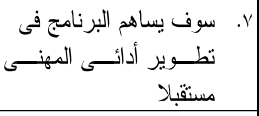 \\
\hline$\cdot, \cdot 1$ & $r \cdot, r$. & $\mid r, r T$ & 1 & $19, \mathrm{iV}$ & o & $A_{\cdot}, \cdot, \cdot$ & $r \leqslant$ & 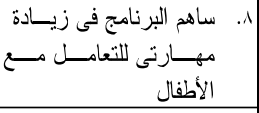 \\
\hline$\cdot, \cdot 1$ & $r q, \varepsilon$. & 1. & $r$ & $1, \ldots$ & $r$ & $A_{1}, \cdots$ & $r \varepsilon$ & ". ساعلية فى إدارة وقتى \\
\hline,+1 & 10 & $17, \mathrm{VV}$ & ० & $17, \mathrm{iV}$ & o & $74,7 \mathrm{~V}$ & $r$. & كان وقت البرنامج مناسب \\
\hline
\end{tabular}

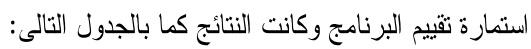
جول (11) النكر ارات و النسب المئوية لتقييم الطالبات للبرنامج

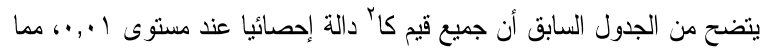

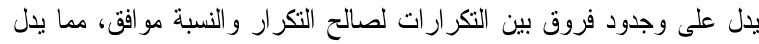
على أن البرنامج ذات فعالية فى تحقيق أهدافه.

مانم النتائجة:

1. توجد فروق ذات دلالة إحصائية بين القياس القبلى و البعدى للمجموعة التجريبية

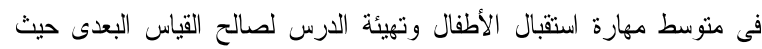

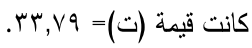

r. توجد فروق ذات دلالة إحصائية بين القياس القبلى و البعدى للمجموعة التجريبية

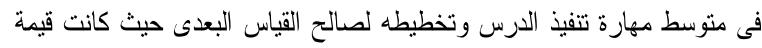

$$
r \cdot, V r=(ت)
$$

r. توجد فروق ذات دلالة إحصائية بين المجموعة الضابطة والمجموعة التجريبية

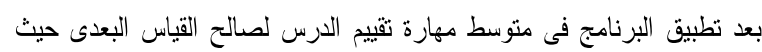

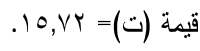

؛. توجد فروق ذات دلالة إحصائية بين القياس القبلى و البعدى للمجموعة التجريبية

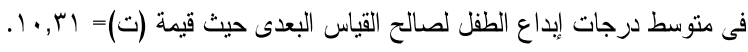

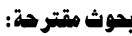

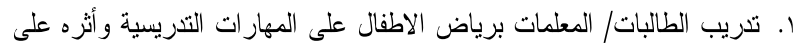

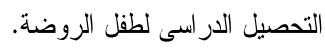
r. العلاقة بين توجهات الاتثان عند الطالبة/ المعلمة و ابداع طفل الروضة.

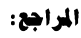

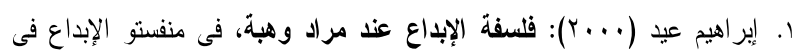

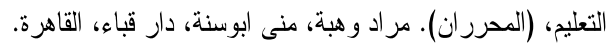

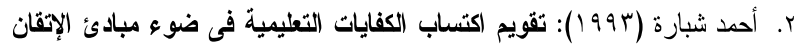
لاى طالبات الكلية المتوسطة للمعلمات بمسفط. التربية المعاصرة، رابطة التربية الحديثة، القاهرة. r. آمال أحمد مختار صادق (؟991): تنمية الإبداع فى الفنون عند تلاميذ مرحلة

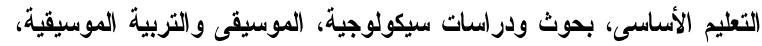
مكتبة الأنجلو المصرية. 
Publishing Company, New York.

38. Austin, E. L., (2007): Standards for teacher competence in http:// www.allacademic.com/meta/p106668 index.htm Kindergartn, Education Assessment of students, Paper presented at the annual meeting of the American Sociological Association.

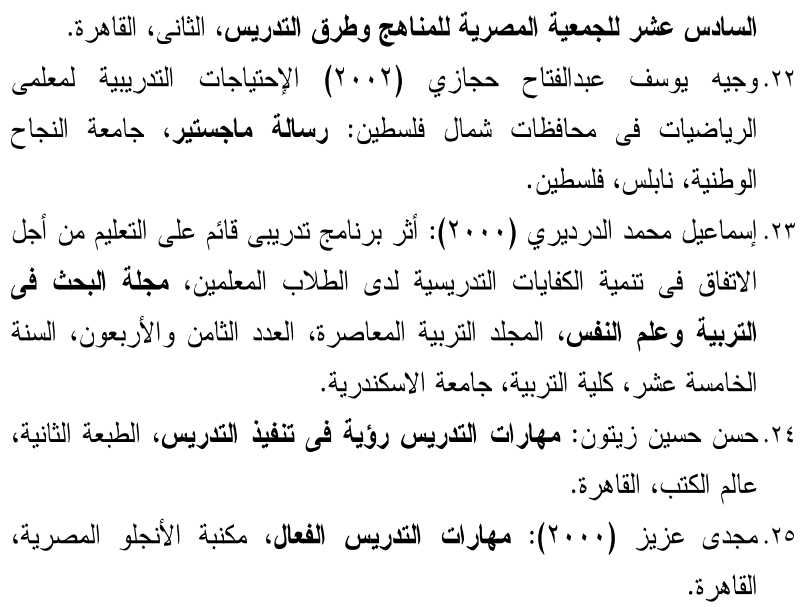

26. Al Ajami, M, (1994): Teachers Attitudes Towards Creativity and Their Instructional Behaviors in the Classroom. Dissertation Abstracts International, (10), P; 30- 71

27. Carr, J. (1998): Information and Literacy and Teacher Education. Eric Digest, 796012. 41.

28. Hamza, M. K, (1997): Exploration in Teaching Strategies that Foster Creative Thinking and Problem Solving in A Community College Un Published DA

29. Lim, C.\& Able Boone, H (2005): Diversity Competencies within Early childhood teacher preparation innovative practices and future Direction. Journal of Early childhood teacher Education. v(26). N(3)$\mathrm{p}(225-238)$. Jul.

30. National Council of Teachers of Mathematics (NCTM) (1998): Child development, New Orleans, LA, March.

31. Schonewill, B.\& Van der Leij, A. (1993): Ethnic background classroom instruction and child behavior in kin derogate: the roie of the teacher to stimulate children in the classroom by giving individual attention. European Early Childhood Education R esearch Journal, Jan. V (1) N (2). p11- 25, 15

32. Selven, Eileen (2003), Basic Performance competency and Measure if Teachers Doing it in Kindergarten, Recourses for Education, ERIC $\mathrm{ED}(47686)$.

33. Tollefrud Aderson, Linda (1993); "Counting and number conservation", Paper Presented at the Biennial meting of the society for research.

34. Von Eschenbach, John F. \& Pavlak, Stephen, A. (1993); Importance and affainment of teacher certification competencies as perceived by principals and teachers. Paper presented at the Amnual meeting of Eastern Educational Research conference Clearwater, Florida, Feb. 1993, (22P)

35. Jane, G. (2012): Toward the Effective Teaching of New Colloge and Career- Ready Standers: Making Professional Learning System, National Comprehensive Center for Teacher Quality. p75

36. Barbara, dona, (2009): Improving Teachers Competency Based Training Program For Beginning The year, $\mathrm{Vol}(78), \mathrm{No}(22), \mathrm{pp} 256$

37. Coop, Gorge I, (2006): Increasing Teacher Effectiveness, Macmillan 